\title{
Flood risk (d)evolution: disentangling key drivers of flood risk change with a retro-model experiment
}

Andreas Paul Zischg ${ }^{1,2}$, Patrick Hofer ${ }^{2}$, Markus Mosimann ${ }^{1,2}$, Veronika Röthlisberger ${ }^{1,2}$, Jorge 5 A. Ramirez ${ }^{2}$, Margreth Keiler ${ }^{1,2}$, Rolf Weingartner ${ }^{1,2}$

${ }^{1}$ University of Bern, Oeschger Centre for Climate Change Research, Bern, 3012, Switzerland

${ }^{2}$ University of Bern, Institute of Geography, Bern, 3012, Switzerland

Correspondence to: Andreas Paul Zischg (andreas.zischg@giub.unibe.ch)

10 Abstract. Flood risks are dynamically changing over time. Over decades and centuries, the main drivers for flood risk change are influenced either by perturbations or slow alterations in the natural environment or, more importantly, by socio-economic development and human interventions. However, changes in the natural and human environment are intertwined. Thus, the analysis of the main drivers for flood risk changes requires a disentangling of the individual risk components. Here, we present a method for isolating the individual effects of selected drivers of change and selected flood risk management options based on a model experiment. In contrast to purely synthetic model experiments, we built our analyses upon a retro-model consisting of several spatiotemporal stages of river morphology and settlement structure. The main advantage of this approach is that the overall long-term dynamics are known and do not have to be assumed. We used this model setup to analyse the temporal evolution of the flood risk, for an ex-post evaluation of the key drivers of change, and for analysing possible alternative pathways for flood risk evolution under different governance settings. We showed that in the study region the construction of lateral levees and the consecutive river incision are the main drivers for decreasing flood risks over the last century. A rebound effect in flood risk can be observed following an increase in settlements since the 1960s. This effect is not as relevant as the river engineering measures, but it will become increasingly relevant in the future with continued socio-economic growth. The presented approach could provide a methodological framework for studying pathways for future flood risk evolvement and for the formulation of narratives for adapting governmental flood risk strategies to the spatio-temporal dynamics in the built environment. 


\section{Introduction}

30 Floods are one of the most damaging natural hazards, accounting for a majority of all economic losses from natural hazards worldwide (UNISDR, 2015). Managing flood risks requires knowledge about hazardous processes and their impacts. Risk resulting from floods is defined as a function of the probability of a flood event or scenario, respectively, and the related extent of damage (Fuchs et al., 2005). The latter is computed by a function of the monetary value of the object affected by the flood and its vulnerability against process magnitude.

35 However, the single factors of the risk formula are evolving over time, as well as the resulting risk. Consequently, flood risks are being more frequently analysed from a dynamical perspective rather than from a static one (Merz et al., 2010; Mazzorana et al., 2012). Hence, many studies are dealing with changes of natural risks over recent decades and centuries (Keiler et al., 2005; Hufschmidt et al., 2005; Keiler et al., 2006; Himmelsbach et al., 2015; Achleitner et al., 2016). In addition, research on climate change and their impacts is focusing on future changes

40 in risks (Hundecha and Merz, 2012; Beckers et al., 2013; Hirabayashi et al., 2013; Merz et al., 2014; Alfieri et al., 2015a; Alfieri et al., 2015b; Devkota and Bhattarai, 2015; Alfieri et al., 2016; Arnell and Gosling, 2016; Kundzewicz et al., 2014). Only a few studies consider both, the impacts of climatic changes to river flows and the future dynamics in the elements at risk (Bouwer et al., 2010; Jongman et al., 2012; Liu et al., 2015; Winsemius et al., 2015; Löschner et al., 2016). However, most studies focus on the future increase of flood risk. To our

45 knowledge, a closer look at the dynamics of the change itself is rather rare.

Several intertwined natural and anthropogenic drivers influence the spatio-temporal evolution of flood risk in floodplains. Floods are either caused by direct rainfall on the floodplain (pluvial floods, surface water floods) or rainfall on river catchments resulting in catchment outflow. The latter is causing floods in downstream floodplains (riverine floods, lake floods). Thus, the boundary conditions of floods in a floodplain can either be rainfall or river

50 flow, or both. Consequently, changes in flood processes, i.e. changes in frequency and magnitude of floods in a floodplain, are determined by these external influencing factors. In several studies, the changes in rainfall frequency and intensity are investigated, with a special focus on the effects of climatic changes (Gobiet et al., 2014; Arheimer and Lindström, 2015). Thus, changes in the incoming flow hydrographs are external drivers of change in floodplains (Hollis, 1975; Hooke, 2006; Muñoz et al., 2017). In mountainous areas, flood losses are also influenced by sediment transport and deposition processes (Staffler et al., 2008; Keiler et al., 2010).

River morphology changes over time (Marani and Rigon, 1994; Pinter et al., 2001; Sear and Newson, 2003; Brierley and Fryirs, 2016; Slater et al., 2015) and this can include natural and gradual changes in the river morphology and flood regime (Church and Ferguson, 2015; Coulthard and Van De Wiel, Marco J., 2007; Hall et 
al., 2014; Herget et al., 2007; Marchese et al., 2017; Vorogushyn and Merz, 2013; Arnaud-Fassetta, 2003),

60 changes in the adjacent vegetation (Corenblit et al., 2014), or disruptive changes by flood events (Guan et al., 2016), e.g. by levee failures (Croke et al., 2015). Also important are anthropogenic interventions that are relevant drivers of flood risk in a floodplain, for example the construction of flood defences such as levees and dams (Pinter et al., 2000; Belz et al., 2001; Surian and Rinaldi, 2003; Bronstert et al., 2007; Di Baldassarre et al., 2009; Ernst et al., 2010; Bergillos et al., 2016) or river restoration projects (Kiss et al., 2008; Dixon et al., 2016). Changes in 65 river morphology can be captured by reconstructing the morphology of historic states of the river and comparing it with the present state. This concept of retro-modelling was first defined by Remo and Pinter (2007) and Remo et al. (2009). Retro-modelling provided a methodological framework for some of these mentioned studies. However, the construction of levees as flood protection measures in one floodplain can have adverse effects in downstream floodplains (Tobin, 1995; Pinter et al., 2006; Gregory, 2006; Zhao and Shao, 2015; van Triet et al.,

70 2017) and can result in trade-offs in flooding between upstream and downstream floodplains (Ryffel et al., 2014; Salzmann et al., 2016). Likewise, land use changes impart an effect on catchment hydrology and floods (Burby and French, 2007; O'Connell et al., 2007; Rogger et al., 2017). For example, drainage of land for settlement or agriculture can incur subsidence that results in increasing flood hazards and flood risk (Carisi et al., 2017).

Beside changes in the natural environment, i.e. the fluvial aspect of the floodplain, flood risk is also changing due to variations in the exposed elements at risk and their vulnerability. One of the most relevant drivers of flood risk is the increase in the elements at risk due to socio-economic development (Elmer et al., 2012; Fuchs et al., 2015). The growth of settlements and thus the increase of residential buildings is related to population growth (Cammerer and Thieken, 2013). Infrastructure is increasing in parallel with population growth. This has wider impacts on the socio-economic system. For example, in economically active areas, floodplains are increasingly occupied by

80 production facilities, as these require relatively flat areas for their construction (Nicholls and Crompton, 2017). Recent studies in Austria show an increase in the number of buildings potentially affected by floods of up to 700 $\%$ in the last century (Fuchs et al., 2015; Fuchs et al., 2016). With economic development, the elements at risk and the infrastructure in floodplains are increasing in quantity and monetary value. Last but not least, higher object vulnerabilities (Adger, 2006; Posey, 2009; Boudou et al., 2016) due to changes in the construction techniques result in increasing flood risks. Increasing values at risk compete with the opposing drivers of flood risk reduction measures by individuals and the public (Wiering et al., 2017). Hence, changes in exposure and vulnerability are influenced by governmental interventions and regulations and by the actions of individuals (Noël and Cai, 2017). On the one hand, local governments regulate land use with spatial planning instruments. In many countries, the 
occupation and utilization of areas potentially affected by floods is not allowed or restricted. Moreover,

90 governmental institutions and legislative entities are providing the basic principles and legislative frameworks for land use (planning) in floodplains (Gober and Wheater, 2015). Thereby, land use regulations are dictating the actions of the individuals and businesses. Governments and insurance companies are increasingly enforcing individuals to protect their houses against floods with object protection measures.

In summary, the built environment in floodplains, whether the settlement area or the river channel, is subject to changes and co-evolutionary dynamics in both spheres of society and nature (Di Baldassarre et al., 2013a; Di Baldassarre et al., 2015). Floodplains are influenced by flood events and subsequent changes in the society, by governmental decisions as adaptation to these flood events, and individual agents (Di Baldassarre et al., 2013b). These dynamics between society and nature influences past and future risk pathways. Moreover, the spatiotemporal development of all these drivers for change in flood risk leads to difficulties in predicting flood risk.

100 Consequently, recent studies have extended the framework of risk analysis towards a spatio-temporal framework as drivers for flood risk changes are varying in space and time (Ahmad and Simonovic, 2013; Aubrecht et al., 2013; Cammerer et al., 2013; Fuchs et al., 2013; Früh-Müller et al., 2015; Fuchs et al., 2016; Röthlisberger et al., 2016).

The main problem in estimating future risks and spatio-temporal dynamics in risk components is that a study design has to be based on assumptions of the future development of societal and natural drivers of flood risk. Thus, the future pathways of evolving flood risks could be remarkably diverse and risk predictions might be uncertain. We aim at closing this gap by proposing a model experiment, in which the evolution of the considered drivers for flood risk is known. The main research questions are how to set up the model experiment in a way that it enables a disentangling of the main drivers of change and how alternative pathways of flood risk evolution

110 could be simulated. Essentially, we want to know how flood risk would have developed over the last 100 years if society had implemented nature based solutions for flood risk management rather than technical solutions involving river corrections. Herein, our hypothesis is that a multi-temporal (retro-) model of the floodplain allows to capture flood risk change in a spatially explicit way and to disentangle the main drivers of change.

\section{Study area and methods}

115 The key for disentangling the different drivers of change is to elaborate spatial datasets representing different states in time of each selected driver. In our model experiment, we consider the following drivers of change as they evolved though the time period 1820-2015: a) the river morphology and b) the size and structure of the 
settlement. Two processes, the construction of levees and the consecutive river incision influence the first driver.

The model experiment is set up in a multi-temporal mode. This includes the creation of digital elevation models

that represent historic states of the river morphology. In the model experiment, the different states of the river morphology (retro-models) are combined with different states of the building dataset. In addition, alternative development pathways are analysed by assuming the introduction of selected land use regulation strategies at an early point in time. The combination of the temporal states of the river and the settlement leads to the isolated quantification of the effects of each selected driver of change. An overview of the method is given in figure 1.

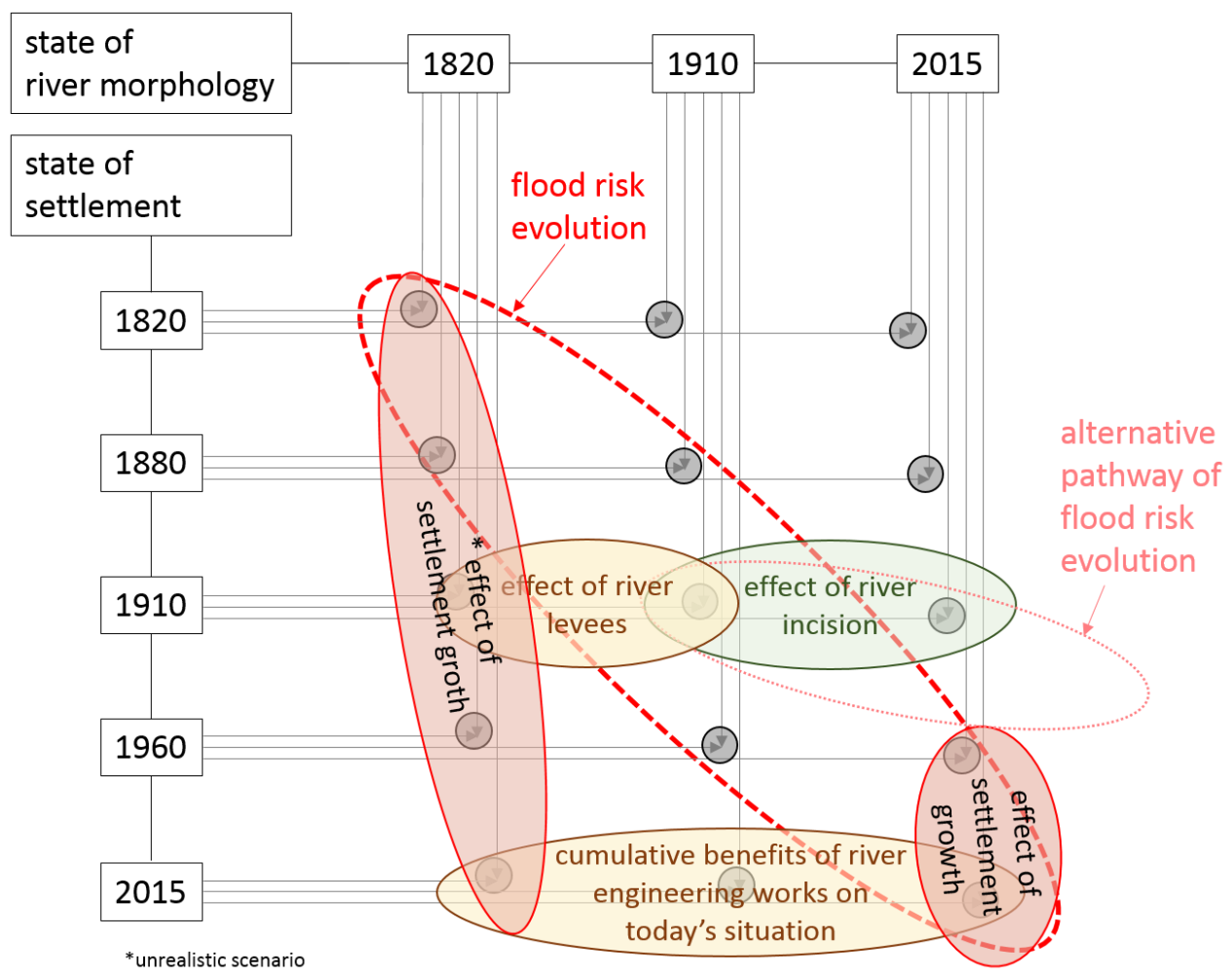

Figure 1: Overview of the model experiment. The different states of the river morphology are combined with different states of the settlement. The combinations allow to analyse the key drivers of flood risk change in isolation. The timesteps are defined by the availability of historic data sources and maps.

\subsection{Study area}

The proposed approach of isolating the key drivers of flood risk change in a model experiment was developed in a case study where the necessary multi-temporal datasets of both river morphology and settlement structure are available. In Switzerland, the technology for river engineering and corrections spread in the early $19^{\text {th }}$ century. One of the first relevant river corrections took place as early as in 1714 with the Kander River deviation (Wirth et al., 2011). In 1807 the Linth River was corrected (Vischer, 2003), and in 1824 the Aare River was corrected following the general zeitgeist of the era of river engineering. In the framework of preparatory planning of these 
river correction works, the engineers measured mean water flows at many cross sections and made astonishingly exact surveys of the natural river topography. These data are available in the archives of the public authorities. In our study, we focus on the floodplain of the Emme River between Burgdorf and Gerlafingen (Canton of Bern, Switzerland, see figure 2). The Emme River drains a river catchment of $963 \mathrm{~km}^{2}$ upstream of the study area. The mean altitude of the pre-alpine catchment is about $860 \mathrm{~m}$ a.sl. The size of the study area is $55 \mathrm{~km}^{2}$.

\section{Historic development of river morphology and settlements in the study area}

The floodplain experienced a devastating and well-documented flood event in 1764. After this flood event, the authorities began with the installation of simple wooden river stabilisation measures. Moreover, after the flood events 1868 and 1876, the federal and cantonal authorities decided to regulate the main river course of the Emme, and in 1884 they began with the construction of lateral dikes. In the following decade, the narrowed riverbed incised by up to $2.4 \mathrm{~m}$. Consequently, soon after the first anthropogenic modifications the erosion had to be stopped by the construction of riverbed stabilisation measures. Hence, this case study shows exemplarily a highly dynamic evolvement of a natural river towards an anthropogenically modified river. Additionally, the floodplain experienced a considerable economic growth in the late $19^{\text {th }}$ and throughout the $20^{\text {th }}$ century. This has been reflected by a population increase as well as by the number of houses.

The dates for the reconstruction of the historic states of the floodplain are mainly determined by the availability of reliable historic sources and relevant dates with abrupt changes in parts of the study area. The present day situation represents the status of the river morphology and the status of the settlements in the year 2015. The most recent datasets are available for this year. The furthest point back in time with reliable data for reconstructing the natural state of the floodplain is the year 1820. For this year, reliable historic surveys were available. A map from the year 1820 allowed the reconstruction of the settlements. Between 1880 and 1910, the river corrections took place with the construction of lateral levees. Hence, a map dated by 1910 allowed to reconstruct both the river and the settlement models. After the construction of lateral levees, the riverbed incised remarkably. The incision stopped only in the 1960s after the construction of transverse structures for riverbed stabilization. Since then, the river morphology did not change substantially. We reconstructed the state of the settlements in 1960 to capture the relevant increase of the settlements in this economically prosperous period. 


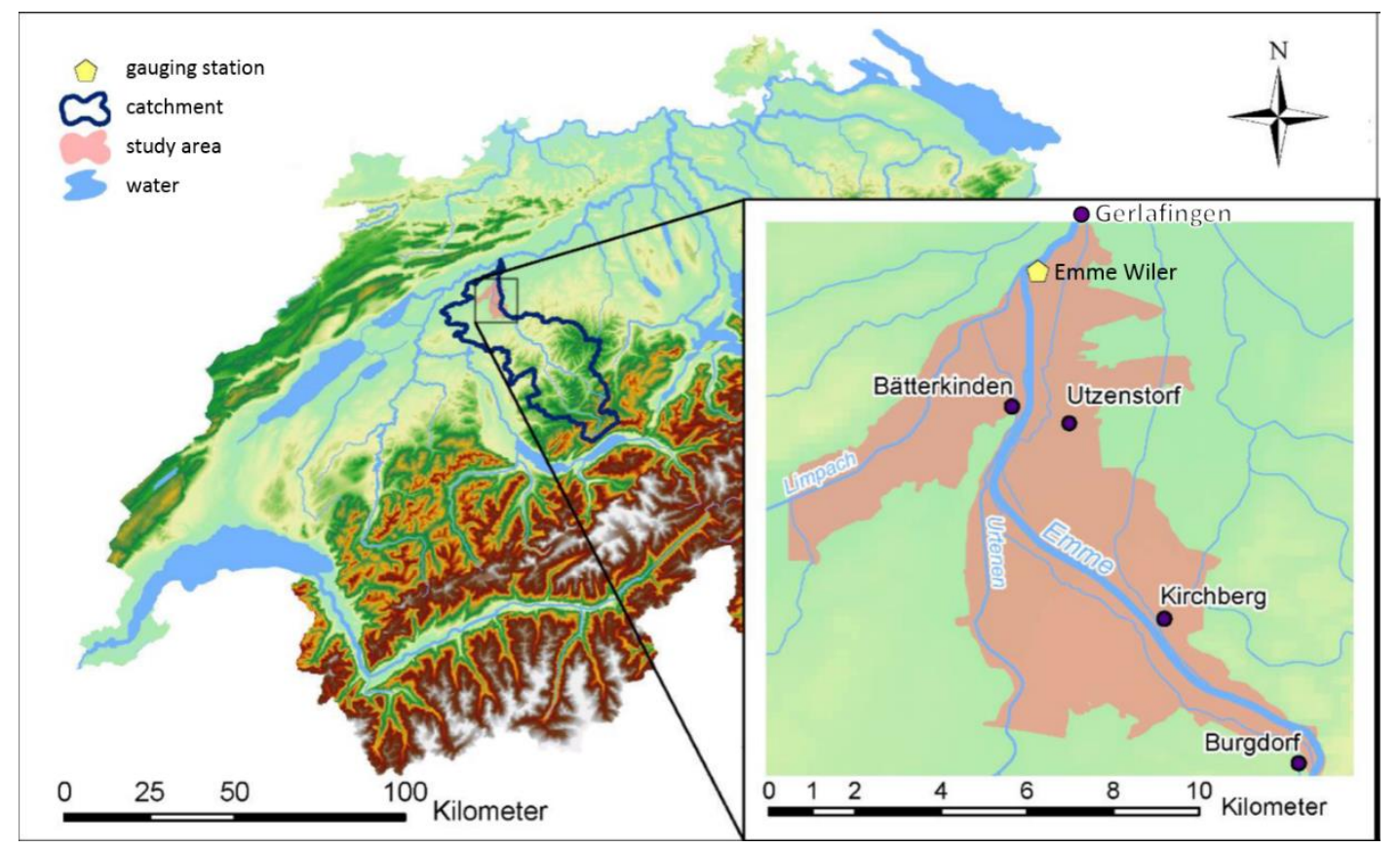

Figure 2: Overview of the study area, the floodplain of the Emme River downstream of Burgdorf, Switzerland.

\subsection{Model experiment}

The model experiment was based on the combination of different states of the floodplain in time. We focused on the evolution of flood risk since 1820 and on the comparison of the effects of selected driving forces for flood risk change, i.e. the effects of changing river morphology and the effect of settlement growth. From now on, we use the abbreviation SRS for the state of the river morphology and SSS for the state of the settlement. We used the following combinations of specific states of these factors for answering the research questions:

- The evolution of flood risk is quantified by analysing the flood risk in the years 1820 (SRS $1820 \cap$ SSS 1820), 1880 (SRS $1820 \cap$ SSS 1880), 1910 (SRS $1910 \cap$ SSS 1910), 1960 (SRS $2015 \cap$ SSS 1960), and 2015 (SRS $2015 \cap$ SSS 2015). According to the historic maps, the river morphology was relatively stable before the river corrections and after 1960. Between these selected points in time, we assumed a linear trajectory of flood risk evolution because temporal states in between the selected ones are unknown.

- The effects of river levees are analysed by comparing the states before and after the construction works, i.e. comparing the combination SRS $1820 \cap$ SSS 1910 with the combination SRS $1910 \cap$ SSS 1910 . 
- To analyse the effects of river incision on flood risk, we compared the two following states: SRS 1910 $\cap$ SSS 1910 and SRS $2015 \cap$ SSS 1910. This scenario isolates the effect of river incision by ignoring the effect of the increasing settlements.

- To capture the effects of urbanisation in the 1960s and thereafter, we compared the states of the settlements in 1960 and 2015 in a constant river morphology (SRS $2015 \cap$ SSS 1960 vs. SRS $2015 \cap$ SSS 2015).

In addition to the analysis of the actual development of flood risk, we hypothesized alternative pathways of flood risk development. For these analyses, we used the following hypothetical combinations of specific states of river morphology and settlement:

- Do-nothing: In a baseline hypothetical scenario of the model experiment we explored no interventions for flood risk management. This scenario consists of the river morphology in 1910 with present day buildings (SRS $1910 \cap$ SSS 2015) and represents a 'do-nothing' policy. For comparison, this scenario is trialled with the combination SRS $2015 \cap$ SSS 2015 to answer the question of how many buildings are benefitting today from the decisions made more than 100 years ago. In other words, this comparison quantifies the cumulative benefits of historic river engineering works on today's situation.

Moreover, we analysed the effects of an introduction of land use planning at an early point in time and thus the long-term effect of this kind of risk management policy. The municipalities in Switzerland have to consider hazard maps in their land use regulation plans. Depending on the hazard zone, the construction of houses is regulated or restricted. A description of the land use regulation policy is given in Appendix A. The actual hazard maps have been incorporated into the municipal land use regulation plans in the period 2009-2015. The effect of this relatively recent intervention can only be quantified several years after implementation. Thus, we analysed the effects of an early implementation of the hazard maps on flood risk reduction. Considering hazard maps and land use regulation policy the following scenarios were developed:

- Hypothetical land use regulation scenario 1: Land use regulation only. In this experiment, we asked how many buildings occupied by people would not have been built in restricted areas (red hazard zones) if the hazard mapping regulation had been introduced in 1910 instead of in the 2000s. We elaborated a hazard map for the river morphology in 1910 following the actually valid guidelines for hazard mapping in Switzerland (see Appendix A). From the buildings dataset, we removed all the buildings that had been constructed in the red hazard zone (high hazard level) after the hypothetical implementation of the hazard map in 1910. This scenario shows an alternative pathway of flood risk development under strict land-use 
regulation over 100 years, starting from a relatively natural state of the river and following a naturebased flood risk management strategy.

\section{- Hypothetical land use regulation scenario 2: Land use regulation combined with object protection} measures. This scenario is based on the same assumptions as hypothetical scenario 1, but in addition we assumed that house owners in the blue hazard zones (medium hazard) implement object protection measures reducing the vulnerability of buildings by $50 \%$, e.g. by sealing of house entrances or cellar windows to reduce the probability of water entering the house.

- Hypothetical land use regulation scenario 3: Alternative policy. This scenario hypothesises the effects of an alternative land use regulation policy. Here, we implemented an alternative to the Swiss hazard mapping approach, by hypothetically adopting the Bavarian policy for hazard mapping. The main aspect of this policy is to avoid construction of houses in the area flooded by a 100-year flood event, irrespectively of the flow depths. As in the first and second hypothetic scenarios, we removed all the buildings that had been constructed in the regulated perimeter after the hypothetical implementation of this policy in 1910 .

\subsection{Analyses and models required for conducting the model experiment}

225 To conduct the model experiment, three principal components must be prepared. The multi-temporal setup based on a) the retro-models of the river morphology, b) the retro-models of the houses, and c) the flood simulation and flood loss analysis module. In the following, we describe the main components of the model experiment.

\subsubsection{Retro-models of the river morphology}

The starting point of the multi-temporal analysis of changes in the river morphology is the actual situation. We elaborated a hydraulically correct digital elevation model (DEM) on the basis of a Lidar-based DEM with a spatial resolution of 0.5 m (KAWA Amt für Wald des Kantons Bern, 2015). We corrected the heights of the lateral levees with dGPS measurements. Hydraulic obstacles in the river channel (e.g. bridges) were removed, and the river bed below the water surface was interpolated by using surveyed cross sections from the Federal Office for the Environment (FOEN) as described in Zischg et al. (2018b). The result is a DEM that reflects the anthropogenically modified river and its floodplain in 2015 (SRS 2015).

In total contrast to SRS 2015, we created a river channel that closely represents the morphology prior to any human interventions. We reconstructed this relatively natural state of the river by means of historic topographic maps (maps of Dufour and Siegfried from the federal Office for Topography SWISSTOPO) and contemporary 
topographic surveys (Ritter, 1804; Anonymous, 1780-1820, 1820a, 1820b, 1898). The historic terrain models

240 were reconstructed by georeferencing and digitalizing historic maps and historic cross-sections combined with the mapping of the geomorphologic evidences of former river structures in areas not modified by anthropogenic activities (Zischg, 2016). The historic maps and surveys are in a different coordinate system. Thus, we georeferenced the digitalized images with reference points and landmarks that are visible in both the historic and present day maps (see figure 3). We used the high-resolution digital elevation model for georeferencing the historic maps, because the abandoned channels and old branches indicated in the old maps are still visible in the present day DEM. The comparison of the historic maps with the landmarks in the DEM showed a high reliability and accuracy of the historic sources. From the georeferenced historic maps, we digitized the planform of the natural river course. In a subsequent step, we mapped all recent anthropogenic modifications of the terrain in the riverbed and the floodplain and erased these areas from the present day terrain model. In the resulting holes in the DEM, we interpolated a mean surface based on the elevation values at the lateral borders of the erased areas. This results in a terrain model free from artificial and hydraulically relevant landscape modifications. Afterwards, we incised the digitized areas of the historic riverbeds into the historic terrain model. The incision depth was delineated from the historic topographic surveys of cross section geometries. The resulting DEM represents the relatively natural river channel and floodplain in 1820 (SRS 1820, see figure 4). We repeated the procedure to elaborate the DEM of 1910 (SRS 1910) based on the maps of Goldschmied (1913) and Luder (1928). The reconstructed terrain models provided the basis for the creation of the computational mesh for a hydrodynamic model. In 1820, the river course was on average $90 \mathrm{~m}$ wide and the riverbed was about 1-3 $\mathrm{m}$ below the surrounding floodplain. In contrast, the present day DEM has a river width of $42 \mathrm{~m}$ and is on average $3 \mathrm{~m}$ below the natural river bed. 


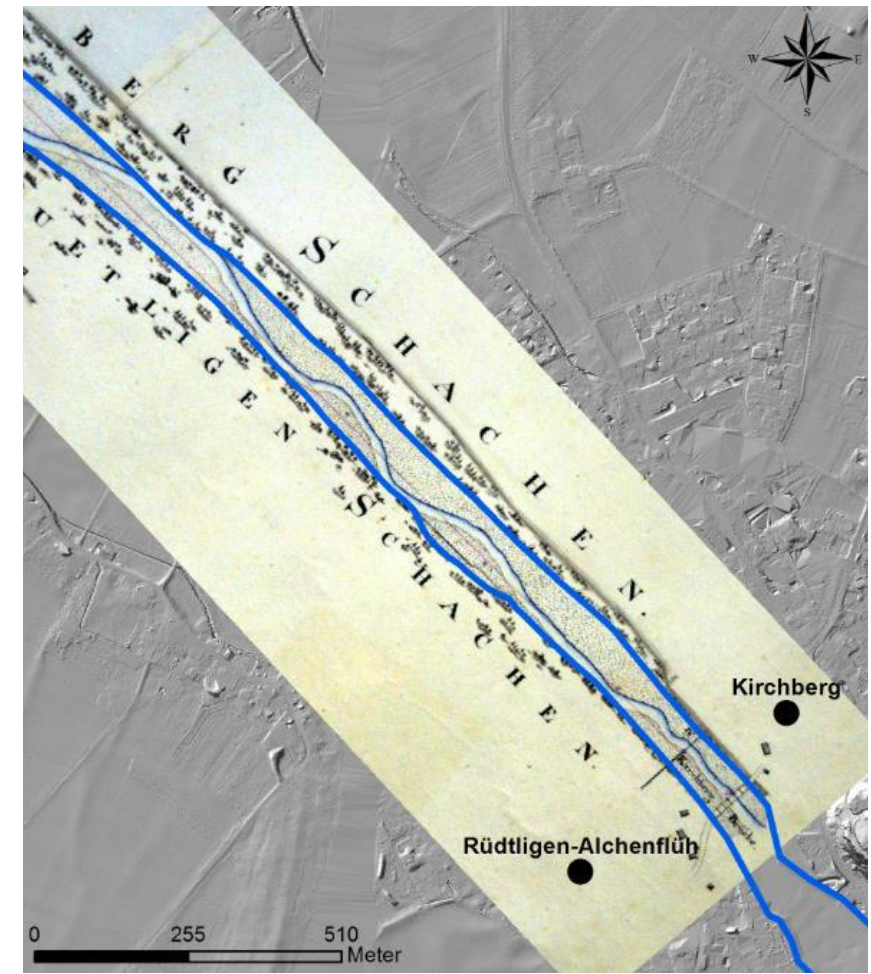

Figure 3: Extract of the historic map of 1820 of the Emme river reach near Kirchberg, Switzerland.
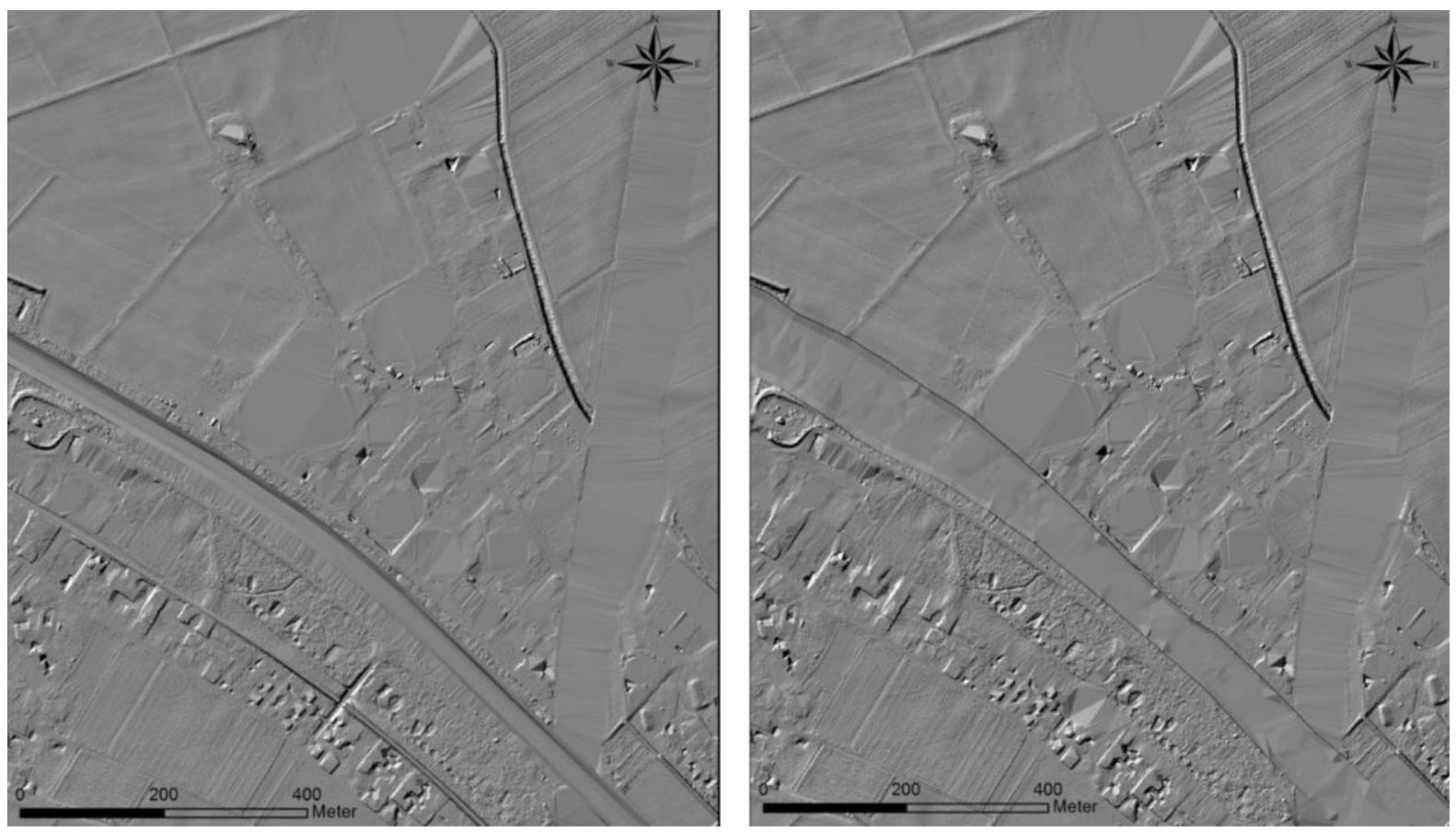

Figure 4: Hillshades of the present day DEM (SRS 2015, left) and historic DEM of 1820 (SRS 1820, right) 


\subsubsection{Retro-models of the elements at risk}

In the analysis of flood risk, we focus explicitly on buildings and houses. In a multi-temporal exposure analysis, the building data set has to be elaborated for selected temporal states. For the present day situation, we used the building dataset elaborated by Röthlisberger et al. (2017). This dataset spatially represents the building's

270 footprints, to which their building value and the number of inhabitants were attributed (SSS 2015). This dataset is based on the digital terrain model of the Federal Office for Topography SWISSTOPO and the residential statistics of the Federal Office for Statistics (FOS). The building value was calculated based on each building's volume, which has been derived from LIDAR measurements. The monetary value was calculated based on average construction prices. This present day situation provided the basis for the retro-models of the settlements.

275 From a copy of this dataset, we removed the buildings which were not present in the topographic maps of 1959 and 1960 (SWISSTOPO). This results in a dataset representing the settlement in 1960 (SSS 1960). The historic Siegfried maps of 1915, 1916, and 1917 lead to a dataset of the settlements in 1910 (SSS 1910). The historic maps of 1871, 1879, 1880 lead to a dataset representing the year 1880 (SSS 1880). Finally, we used the historic Dufour map of the year 1845 (SWISSTOPO) and the maps of Finsler (1978) for reconstructing the status of settlements 280 in 1820 (SSS 1820).

However, we let the reconstruction values, the type of functionality, and the vulnerability of the houses constant over the whole period in the model experiment. This means that the losses vary only with the number of houses exposed to floods and not with the inflation or extension of building values over time.

\subsubsection{Flood simulation and flood loss analyses}

285 The selected spatio-temporal states of the digital terrain models and the buildings provided the basis for a flood loss analysis. For each temporal status of the river morphology, we simulated several flood events ranging from the mean annual flood to an extreme flood.

An important step in this procedure is the preparation of the hydrographs for flood simulation. On the basis of an observed discharge time-series, typical flood hydrographs, i.e. a synthetic design hydrograph, were derived using the guidelines proposed by Serinaldi and Grimaldi (2011). Based on measurements at the river gauging station in the study area, observed hydrographs were normalized in terms of event duration and peak discharge. The resulting dimensionless event hydrographs were superimposed and centered on the peak position. A two parametric gamma distribution function was fitted to represent the typical shape of the event hydrographs, as described by Nadarajah (2007) and Rai et al. (2009). This resulted in a synthetic unit hydrograph that represents a typical hydrograph shape of flood events in the corresponding catchment. The synthetic unit hydrograph was 
scaled to various peak discharges, whereas an empirical peak-volume-ratio was used to determine the corresponding event duration. The procedure was applied to generate synthetic design hydrographs for a continuous series of peak discharges in intervals of $50 \mathrm{~m}^{3} \mathrm{~s}^{-1}$ (figure 5). The occurrence probability of each hydrograph was delineated from the extremal statistics of the gauging station Emme Wiler (provided by FOEN). In general, the delineated synthetic hydrographs represent a typical flood hydrograph. Nevertheless, other event types could potentially occur, as for instance long lasting rainfall events (Brunner et al., 2018). These may have a higher volume than the one assumed while having the same peak discharge. In these cases, the flood losses may be higher.

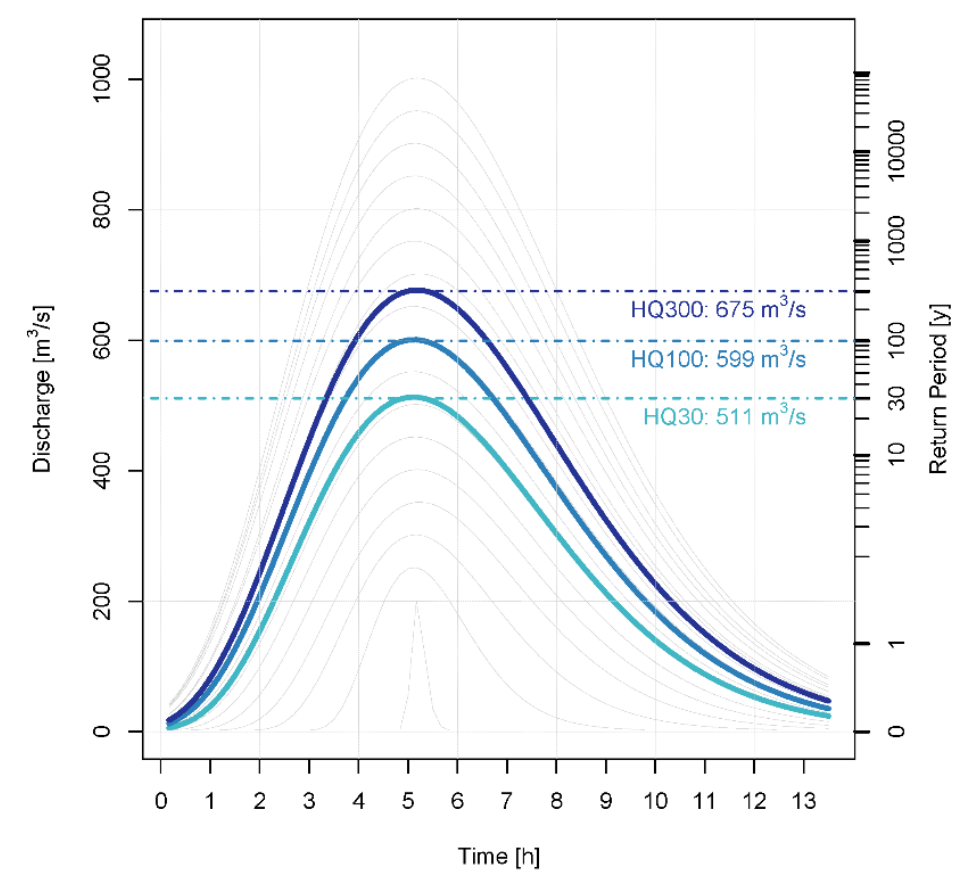

Figure 5: Synthetic hydrographs with an interval of $50 \mathrm{~m}^{3} / \mathrm{s}$ used for the flood simulations. In addition, the three hydrographs used for the elaboration of the hazard maps are shown in bold lines.

In a further step, we developed a flood inundation model in two dimensions (2D) for each floodplain. We used the 2D flood inundation model BASEMENT to represent the water fluxes through the river and its floodplain

310 (Vetsch et al., 2017). It is a numerical model solving the shallow water equations on the basis of an irregular mesh. An irregular mesh was generated from each of the reconstructed DEMs. The model has been validated with insurance claims in nearby case studies and reproduced well historic flood events (Zischg et al., 2018b). We calibrated the friction values of the SRS 2015 inundation model with the stage-discharge relationship at the gauging station at Emme-Wiler (FOEN). The friction value of $31 \mathrm{~m}^{1 / 3} / \mathrm{s}$ (Strickler coefficient) results in a

315 maximum deviation of the model from the stage-discharge relationship of $5 \mathrm{~cm}$ along the range of observations. The river structure is relatively homogeneous along the river reach. Thus, we assumed the same friction value for 
the riverbed across the whole river reach. The average size of the mesh elements is approximately $32 \mathrm{~m}^{2}$ in the river channel and $279 \mathrm{~m}^{2}$ in the floodplain. The main linear structures are considered in the mesh as break lines. As there are no flood events in the floodplains recorded in the past years but a few bank-full discharge flood events, we validated the hydraulic model with the flood events on $08^{\text {th }}$ August 2007 and $24^{\text {th }}$ July 2014 . As in reality, the model simulated a bank-full discharge with no overtopping and consequently no flooding in the floodplain. Hence, the model reproduces the bank-full discharge (water surface elevations max. $15 \mathrm{~cm}$ below dam heights) without overtopping the lateral levees. Moreover, we checked if the simulation model reproduces the weak points known by the official hydraulic engineering authorities, i.e. the locations along the river where water is first overtopping the levees in case of a flood. These weak points have been reproduced by the model and overflowing of the dams is beginning at known locations.

The synthetic design hydrographs were used as upper boundary conditions for the $2 \mathrm{D}$ inundation model of each terrain model. The lower boundary condition is defined as where the water flows out of the model. The flow depths resulting from the hydrodynamic models were attributed to each building by identifying the maximum flow depth of all nodes within the footprint of the building (Bermúdez and Zischg, 2018). This leads to the calculation of the object-specific vulnerability and estimation of object-specific losses (Zischg et al., 2013; Zischg et al., 2018a). Vulnerability functions provide a degree of loss on the basis of the flow depth at the location of the house. The value ranges from 0 (no damage) to 1 (total loss). This degree of loss is subsequently multiplied by the specific reconstruction value of the building. Currently, five vulnerability functions are considered in the damage calculation procedure. We used the functions of Hydrotec (2001), Dutta et al. (2003), Jonkman et al. (2008), Totschnig et al. (2011), and Papathoma-Köhle et al. (2015). The multiplication of the building value of the house with the degree of loss leads to the flood-loss for a specific exposed object (e.g., a single house). The multi-model ensemble of losses calculated with different vulnerability functions was aggregated to an average loss at single building level, as proposed by Figueiredo et al. (2017). The sum of all losses of each flood scenario in the floodplain enters into the "flood peak - flood loss" relationship of the floodplain. The aggregated losses are subsequently multiplied with the probability of the scenario. The flood risk over all scenarios until a return period of 100 years results from the integration of all scenario-related risks (figure 10). Applying a range of scenarios covering the expected flood magnitudes in the river reach offers a differentiated sensitivity analysis of the floodplain against the flood magnitude, and thus non-linear behaviour in the flood peak - flood loss relationship can be detected if present. 


\section{Results and discussion}

The multi-temporal retro-model consists of three states in time of the river morphology and five states in time of the settlement structure. The hydraulic simulations result in three sets of flood scenarios based on the DEMs of the river models. The simulations show the spatial pattern of the floodplain's sensitivity against the flood magnitude. In figure 6 , the set of scenarios are shown in a generalized way. For each mesh triangle, the minimum peak discharge is shown that is needed to flood the respective part of the floodplain. The figure shows the effectiveness of the levees in terms of reducing flooded areas from 1820 (figure 6a), to 1910 (figure 6b) and 2015 (figure $6 \mathrm{c}$ ). The maximum flood considered in this study (with a peak discharge of $1000 \mathrm{~m}^{3} / \mathrm{s}$, corresponding to a return period of 81,800 years) covers an area of $19.5 \mathrm{~km}^{2}$ in the original state of the river while only $13.7 \mathrm{~km}^{2}$ are being flooded in the present day DEM. The river incision reduces the flooded areas by $7.5 \mathrm{~km}^{2}$. This means that the river correction is also remarkably effective in an extreme flood event. More important from the risk point of view, the reduction of flooded areas is more effective in frequent floods. For instance, a flood event with a return period of 30 years (peak discharge of $511 \mathrm{~m}^{3} / \mathrm{s}$ ) covers $11.47 \mathrm{~km}^{2}$ in 1910 while it covers only $0.96 \mathrm{~km}^{2}$ today.
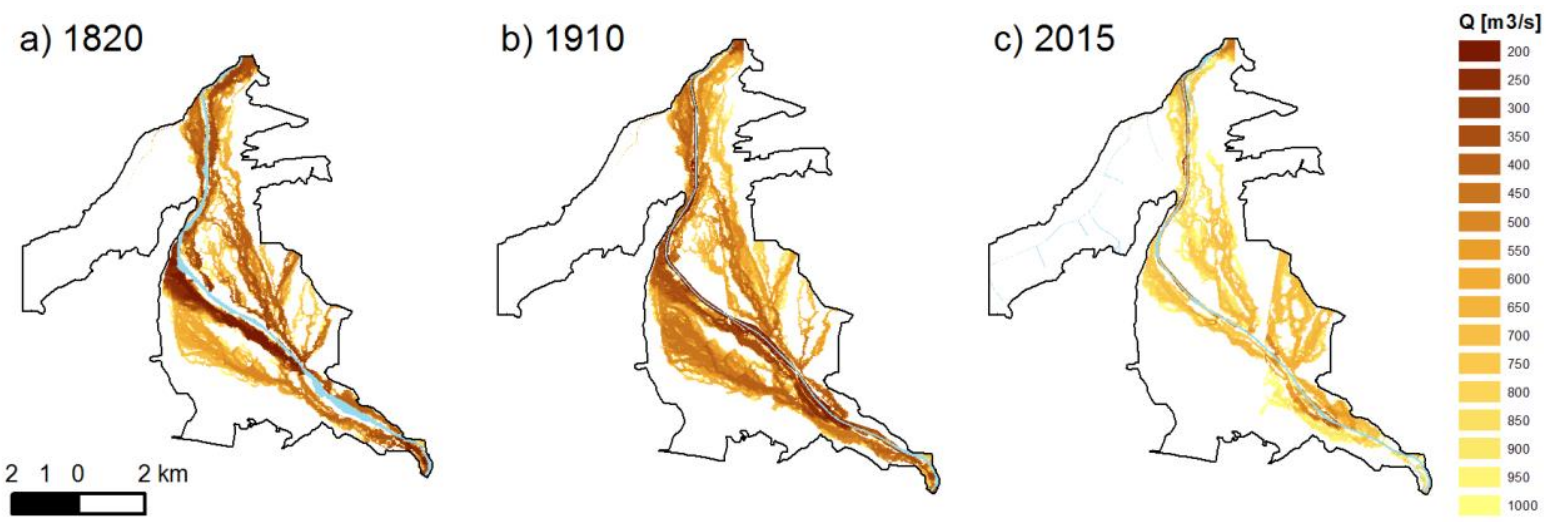

Figure 6: Minimal peak discharge needed for flooding specific locations in the floodplain: a) Flood map of a natural river morphology in 1820, b) flood map of the river morphology in 1910, c) flood map of the present day situation (2015).

In addition to the changes in the river morphology, the settlement structure co-evolved with the river. Figure 7

shows the time stamps of the settlement structure. The settlement in the study area grew by a factor of 10.6 in the period 1820-2015, by a factor of 3.6 in the period 1820-1910, and by a factor of 2.9 in the period 1910-2015. Figure 8 demonstrates the temporal evolution of the settlement aggregated for the whole floodplain of the Emme River. 

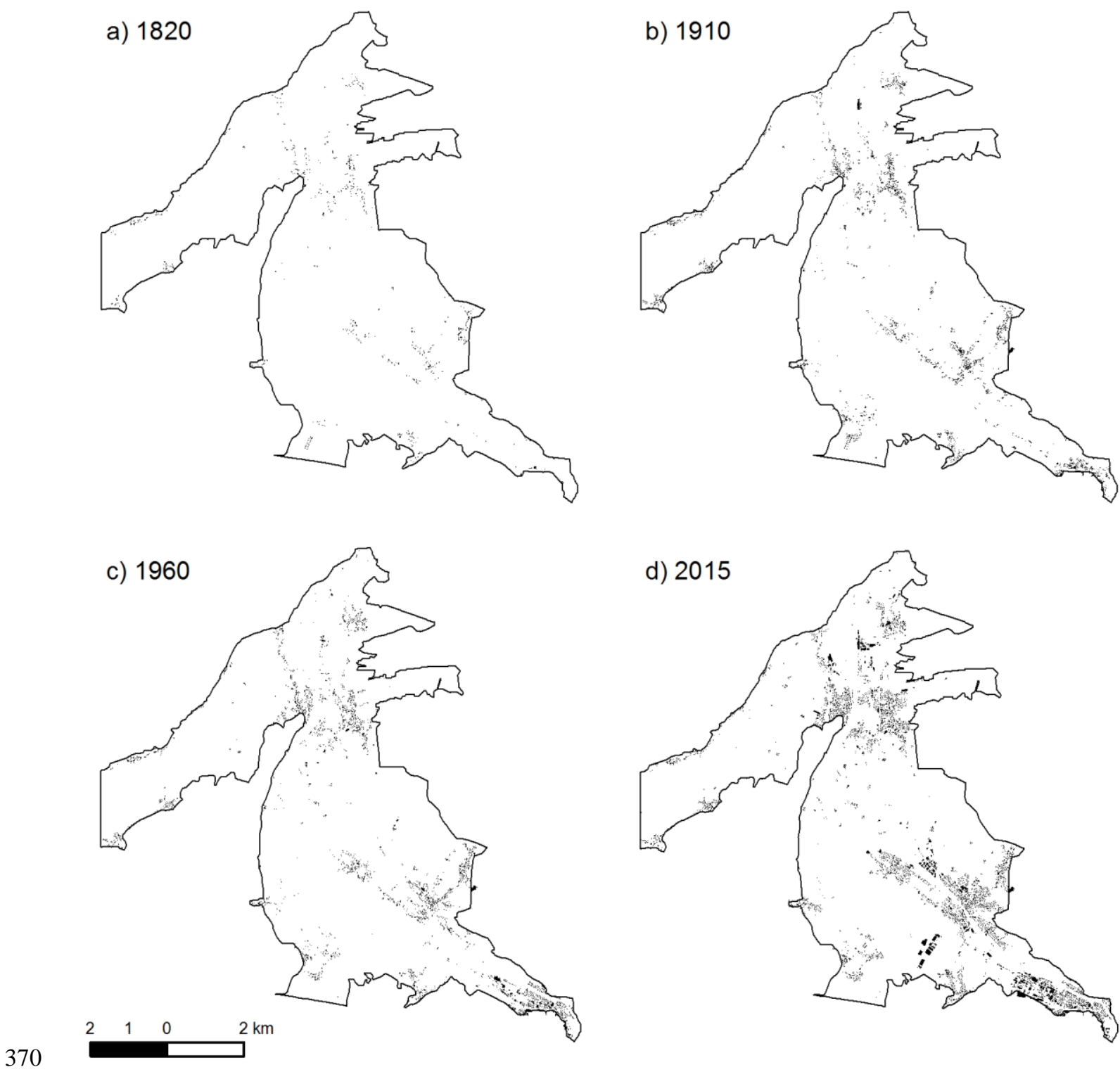

Figure 7: Overview of the spatio-temporal evolvement in settlement structure. 


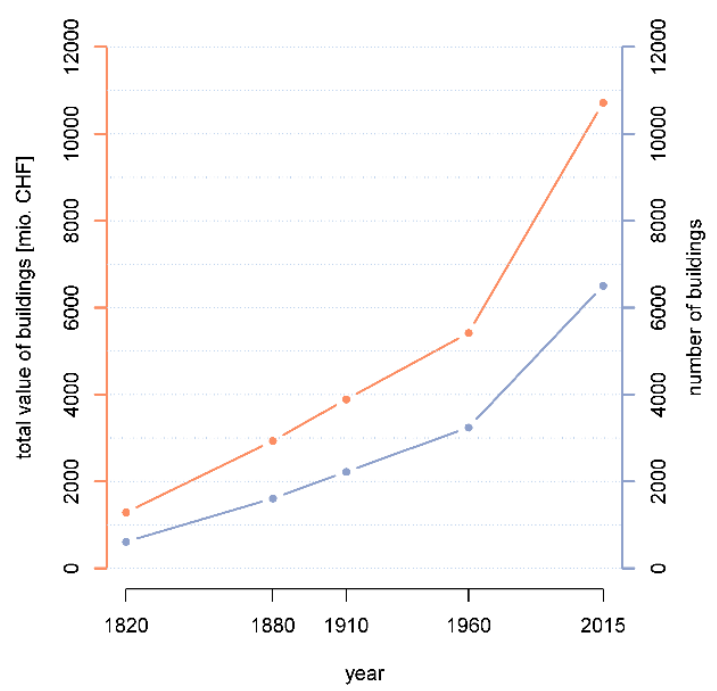

Figure 8: Settlement growth in the study area in the period 1820-2015.

\subsection{Flood risk evolution and drivers of flood risk change}

The shown spatio-temporal dynamics allows the quantification of the flood risk change (figure 10, right). Flood risk in 1820 was in the order of $6.2 \mathrm{mio}$. CHF/year. It increased to 21.6 mio. CHF/year in 1880 , because of the settlement growth. After the construction of the levee, flood risk decreased to 17.3 mio. CHF/year in 1910 and further to $0.6 \mathrm{mio}$. CHF/year in 1960 due to the consecutive river incision. After 1960, flood risk increased again to 3 mio. CHF/year until 2015. In summary, flood risk in 2015 is half (48.4\%, 3.2 mio. CHF/year less) of that in 1820. Surprisingly, flood risk decreased overall in the period 1820-2015, with a rebound effect since 1960.

When looking at the main drivers, the river engineering measures are the most important driver for flood risk change (-42.4 mio. CHF/year, calculated as shown in figure 10b). However, an important part of this flood risk reduction is due to the incision after the construction of the levees. The river incision between 1910 and 1960 increased the river conveyance and resulted in a flood risk reduction of 16.7 mio. CHF/year when assuming SSS 1910 as constant. This is $40.3 \%$ of the total flood risk reduction by the river engineering measures (flood risk change in the period 1880-1960). The engineering works are effective in the full range of peak discharges, meaning that they reduce the losses also in the extremal range of peak of flood magnitudes. Herein, the 'peak discharge - flood loss' relationship, i.e. the loss footprint of the floodplain, allows a closer look at the sensitivity of the floodplain against flood magnitudes (figure 9).

When looking at the effect of the growing settlements, we can observe that this factor constrains the effects of the river engineering measures. From 1960 to 2015, flood risk increased by 2.4 mio. CHF/year (a factor of 5) after a 
period with decreasing risk. As shown in figure 9, exposure increases mostly in the extremal range of flood magnitudes. This diagram shows that the river engineering measures introduce a threshold behavior into the floodplain's loss footprint. In the river morphology of 2015, there are no losses until a certain threshold in flood magnitude. However, beyond this threshold losses increase with a high rate. This means that losses are sensitive against an increase in peak discharge in the upper range of return periods. In contrast, the natural state of the river is less responsive to increasing flood magnitude (figures 9 and 10). Especially in the upper range of floods, the rate of increase in flood losses with peak discharge is much lower than in the present day state. However, the overall losses are much higher.

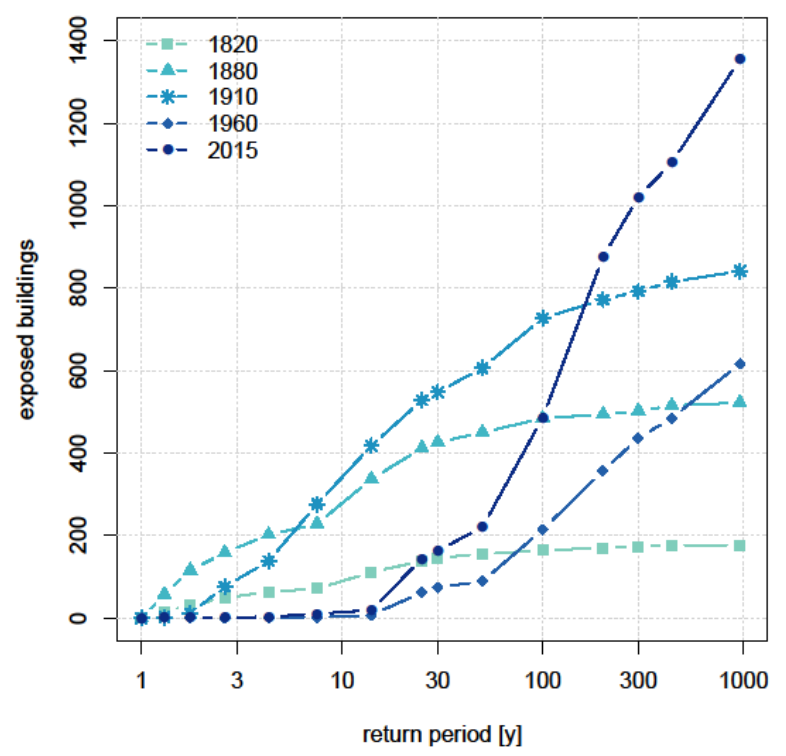

Figure 9: Peak discharge - flood exposure relationships in different states of the floodplain.

\subsection{Alternative pathways of flood risk evolution}

In addition to the identification of the main drivers, we analysed the effects of alternative policies as exemplarily demonstrated by Thaler et al. (2018) for prioritization strategies. The do-nothing strategy, based on the assumption that no interventions are taken, results in a flood risk that is 45.6 times higher than the present day risk (figure

410 10). Thus, the cumulative effect of all river engineering measures of the present day state is a flood risk reduction of 133.9 mio. CHF/year when considering SSS 2015 as the baseline. In absolute numbers, 1950 houses are protected from a 100-year flood when compared with a relatively natural river morphology (SRS 1820). The losses of a 100-year flood are reduced by $84.5 \%$ in comparison to the do-nothing strategy. When assuming the 
state of settlement in 1820 as constant over time in combination with a changing river morphology, the number

of exposed buildings decreased by $85 \%$.

The first hypothetical land use regulation scenario on alternative pathways shows that an introduction of the hazard mapping policy as early as 1910 would have resulted in a flood risk that is 25.5 times higher than the present day risk reduced by river engineering works, but $28.2 \%$ less than in a do-nothing scenario (hypothetical land use regulation scenario 2). In contrast, if an average reduction of the vulnerability of houses against flooding in blue hazard zones by $50 \%$ is considered, this results in a further risk reduction of $28.7 \%$ (in total $56.9 \%$ less than the do-nothing scenario, hypothetical land use regulation scenario 2). Thus, the effectiveness of the actual hazard mapping policy markedly depends on the implementation of object protection measures. Interestingly, the hypothetical consideration of an alternative land use regulation policy (hypothetical land use regulation scenario 3), e.g. the Bavarian land use regulation policy (Drost and Ell, 2016), shows that the effectiveness of different kinds of policies would be remarkably diverse. Under the Bavarian policy the model suggests that risk reduction is in the same range as technical measures. Both technical measures and this policy is aiming at protecting elements at risk up to a design event of a100-year flood. Thus, non-technical interventions can compete with engineering measures (Thieken et al., 2016), but they have to be implemented in a long time horizon, as shown by figure 10 .

a)

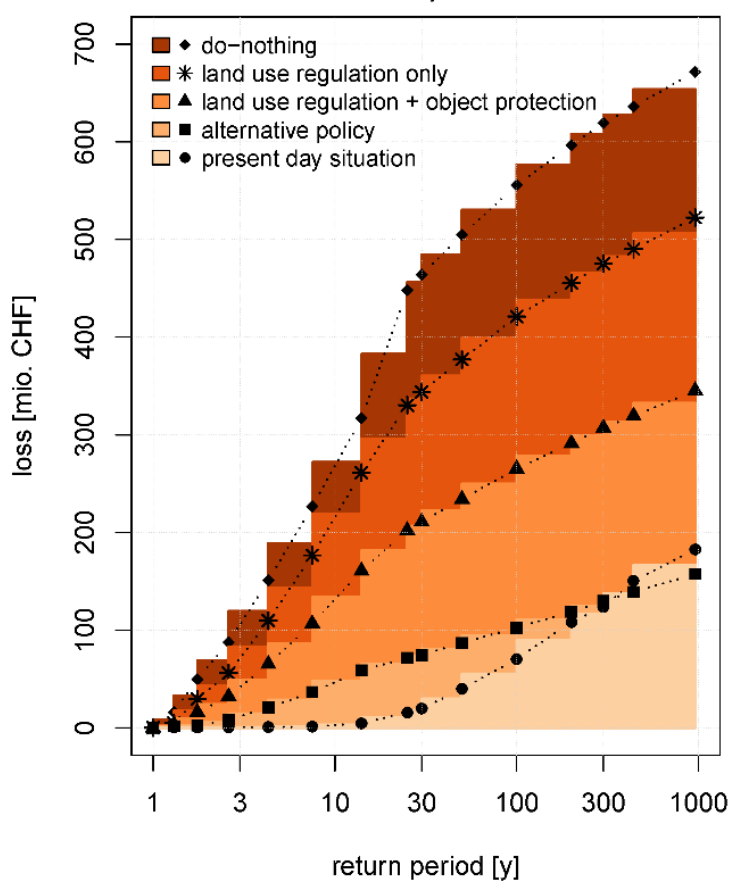

b)

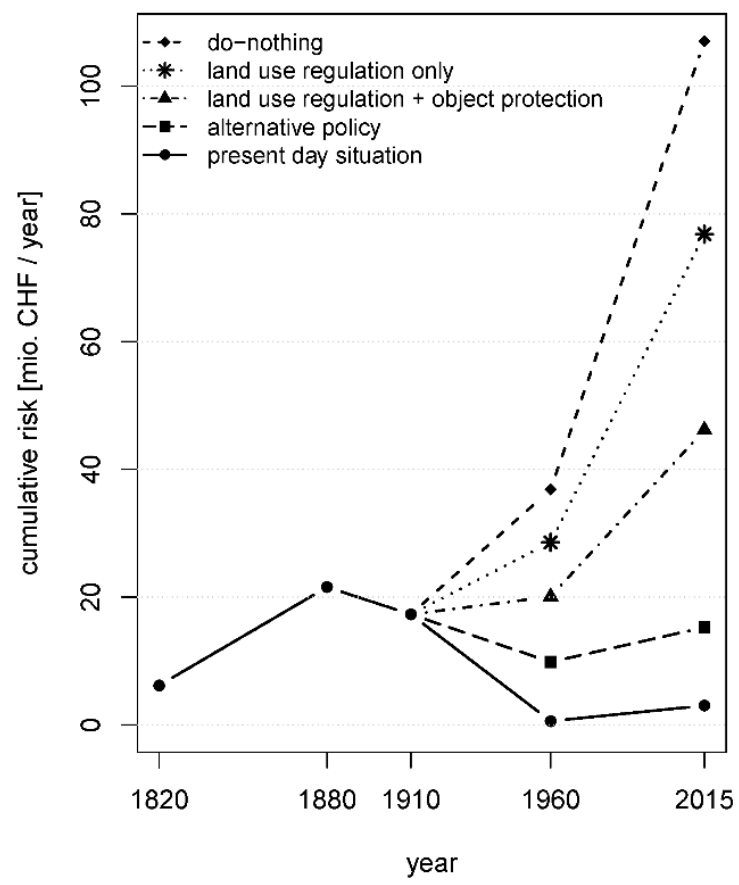

Figure 10: a) Flood loss footprint of the floodplain. b) Trajectory of flood risk evolution and alternative pathways. Hypothetical scenario 1 considers land use regulation only. 


\section{Conclusions}

In the model experiment, we showed that the most relevant of the considered drivers of change in the study region is the human intervention on the river morphology. However, changes of river morphology by the construction of the lateral dams are not the only driver for decreasing risk. The levees alone are effective for flood risk reduction only in the range of frequent floods up to a peak discharge $450 \mathrm{~m}^{3} / \mathrm{s}$ (return period $\sim 14$ years). In contrast, a relevant driver for flood risk reduction is the incision of the river following the construction of the levees. The incision markedly increases the river conveyance and consequently reduces the frequency of flooding in the floodplain. Thus, this secondary effect of the human interventions has also a high relevance for reducing flood risks.

The effects of river morphology that decrease flood risk are partly rebount by an increase of the elements at risk since the 1960s. However, the effects of the drivers that reduce flood risks are more relevant than the effects of the drivers that increase risks. Overall, a decrease in flood risk results.

445 While the results of the model experiment are case-specific, the described retro-modelling experiment approach demonstrated a suitable method for disentangling the main drivers of change in flood risk. Besides disentangling drivers of change, the presented model experiment allows the analysis of alternative pathways. We have shown the isolated effect of land use regulation that restricts the construction of houses in hazard zones. Nevertheless, land use regulation aiming at limiting flood exposure needs a long-term time horizon to become effective.

450 Furthermore, the actual hazard mapping policy is less effective than other concepts of land use regulation, e.g. keeping the flooded area of a 100-year flood event totally free from new constructions. The latter has a higher effectiveness, especially in combination with the strategy of reserving room for rivers, and is applied in other European regions as for example in Bavaria, Germany (Drost and Ell, 2016). If in 1910 this policy had been implemented instead of the river corrections with the following river incision, the risk would only slightly be higher than in the present day situation. Thus, keeping the floodplains free from houses for a long period is nearly as effective as constructive protection measures. Nonetheless, the costs of this policy in terms of missed opportunities due to unrealised economic land use have to be discussed before a final conclusion can be drawn.

We showed that the flood risk is evolving considerably and that it is not necessarily increasing. In contrast, the presented examples show a relevant decrease of the flood risk in the past 200 years. Furthermore, the presented example confirms the so called levee effect (White, 1945), caused by the increase of settlement in floodplains protected by levees. Mainly, overall flood risk in engineered river systems is only increasing due to an increase in residual risks. 
In comparison to fully synthetic model experiments, the study design of the retro-model experiment is based on real data. This means that such a model experiment must not necessarily contain highly uncertain assumptions that are inherent in fully synthetic model experiments. Examples for such assumptions are the growth factor of the settlement, the intervention of governments in the form of hydraulic engineering works, or the spatio-temporal dynamics of settlement evolvement after the introduction of land use maps. All of these dynamics are unknown in prospective experiments. Nevertheless, a retro-model experiment allows analysing alternative pathways of floodplain evolution, by altering one model parameter while letting the others constant.

470 The retro-model has a potential for analysing feedbacks between physical and social processes. With this, the approach may help to understand perspectives for the future by considering the feedback mechanisms between the drivers of flood risk change in the past. This may provide a basis for developing coupled component models of the full flood risk chain from climate, precipitation, floods and losses that consider the spatio-temporal dynamics in both physical and socio-economic components, e.g. considering adaptation efforts in future projections of flood risk. This should eventually lead to sophisticated model chains that consider at least partially the complexity in flood risk evolution. The approach may be furthermore adapted for a risk monitoring program as demanded by Zischg et al. (2013). By quantitatively observing the spatio-temporal dynamics of the single factors in the risk formula, the evolvement of flood risk can be monitored as well.

Last but not least, a retro-model is a reliable basis for the formulation of narratives in climate adaptation (Dessai and Hulme, 2004). They can provide good examples for successful adaptation pathways (Wise et al., 2014) in history. Furthermore, they could be used in risk communication for demonstrating undesired effects of the sum of individual decisions over a long period, and for illustrating how undesired side effects could be avoided by the design of natural flood management options (Lane, 2017; Thieken et al., 2016). However, projections of future adaptation pathways should not be based on past trends identified by retro-models. Furthermore, the presented approach has other important limitations. First, it requires reliable and accurate historic spatial data over a long period and second, the spatio-temporal dynamics of flood risk between the selected time steps are unknown.

\section{Data availability:}

The model experiment is interactively visualized at www.risikodynamik.ch.

\section{Acknowledgments:}

The authors acknowledge the Federal Office for Environment FOEN for providing the data of river cross-sections and gauging station data, the Federal Office for Topography SWISSTOPO for providing basic GIS data, the 
Federal Office for Statistics FOS for providing the residential statistics, and the Canton of Bern for providing the Lidar data and the event documentation data. This work was financially supported by the Mobiliar Lab for Natural Risks.

\section{References}

Achleitner, S., Huttenlau, M., Winter, B., Reiss, J., Plörer, M., and Hofer, M.: Temporal development of flood risk considering settlement dynamics and local flood protection measures on catchment scale: An Austrian case study, International Journal of River Basin Management, 14, 273-285, doi:10.1080/15715124.2016.1167061, 2016.

Adger, W. N.: Vulnerability, Global Environmental Change, 16, 268-281, doi:10.1016/j.gloenvcha.2006.02.006, 2006.

Ahmad, S. S. and Simonovic, S. P.: Spatial and temporal analysis of urban flood risk assessment, Urban Water Journal, 10, 26-49, doi:10.1080/1573062X.2012.690437, 2013.

Alfieri, L., Burek, P., Feyen, L., and Forzieri, G.: Global warming increases the frequency of river floods in Europe, Hydrol. Earth Syst. Sci., 19, 2247-2260, doi:10.5194/hess-19-2247-2015, 2015a.

Alfieri, L., Feyen, L., and Di Baldassarre, G.: Increasing flood risk under climate change: A pan-European assessment of the benefits of four adaptation strategies, Climatic Change, doi:10.1007/s10584-016-1641-1, 2016.

Alfieri, L., Feyen, L., Dottori, F., and Bianchi, A.: Ensemble flood risk assessment in Europe under high end climate scenarios, Global Environmental Change, 35, 199-212, doi:10.1016/j.gloenvcha.2015.09.004, 2015b.

Anonymous: Plan der Güter, die zwischen der Wynigenbrücke und der Kirchbergbrücke an der Emme liegen. Massstab: k.A. Aus: BAB PP 220., 1780-1820.

Anonymous: Plan des Emmen-Bettes von Kirchberg bis Zuchwyl-Brücke. Massstab: 1:5000 (in Bern-Fuss). Aus: StAB AA V 189a-b., 1820a.

Anonymous: Querprofile Emme. StAB AA V 189e-h., $1820 \mathrm{~b}$.

Anonymous: Emme, Mittellauf: Querprofile der beiden Ufer von km 15-34. Aus: StAB AA V 199a., 1898.

Arheimer, B. and Lindström, G.: Climate impact on floods: changes in high flows in Sweden in the past and the future (1911-2100), Hydrol. Earth Syst. Sci., 19, 771-784, doi:10.5194/hess-19-771-2015, 2015. 
Arnaud-Fassetta, G.: River channel changes in the Rhone Delta (France) since the end of the Little Ice Age:

Geomorphological adjustment to hydroclimatic change and natural resource management, CATENA, 51, 141-172, doi:10.1016/S0341-8162(02)00093-0, 2003.

Arnell, N. W. and Gosling, S. N.: The impacts of climate change on river flood risk at the global scale, Climatic Change, 134, 387-401, doi:10.1007/s10584-014-1084-5, 2016.

Aubrecht, C., Fuchs, S., and Neuhold, C.: Spatio-temporal aspects and dimensions in integrated disaster risk management, Nat Hazards, 68, 1205-1216, doi:10.1007/s11069-013-0619-9, 2013.

Beckers, A., Dewals, B., Erpicum, S., Dujardin, S., Detrembleur, S., Teller, J., Pirotton, M., and Archambeau, P.: Contribution of land use changes to future flood damage along the river Meuse in the Walloon region, Natural Hazards and Earth System Sciences, 13, 2301-2318, doi:10.5194/nhess-13-2301-2013, 2013.

Belz, J. U., Busch, N., Engel, H., and Gasber, G.: Comparison of river training measures in the Rhine?:

Catchment and their effects on flood behaviour, Maritime Engineering, 148, 123-132, doi:10.1680/maen.148.3.123.40103, 2001.

Bergillos, R. J., Rodríguez-Delgado, C., Millares, A., Ortega-Sánchez, M., and Losada, M. A.: Impact of river regulation on a Mediterranean delta: Assessment of managed versus unmanaged scenarios, Water Resour. Res., 52, 5132-5148, doi:10.1002/2015WR018395, 2016.

Bermúdez, M. and Zischg, A. P.: Sensitivity of flood loss estimates to building representation and flow depth attribution methods in micro-scale flood modelling, Nat Hazards, 14, 253, doi:10.1007/s11069-018-3270-7, 2018.

Boudou, M., Danière, B., and Lang, M.: Assessing changes in urban flood vulnerability through mapping land use from historical information, Hydrol. Earth Syst. Sci., 20, 161-173, doi:10.5194/hess-20-161-2016, 2016.

Bouwer, L. M., Bubeck, P., and Aerts, J. C.J.H.: Changes in future flood risk due to climate and development in a Dutch polder area, Global Environmental Change, 20, 463-471, doi:10.1016/j.gloenvcha.2010.04.002, 2010.

Brierley, G. J. and Fryirs, K. A.: The Use of Evolutionary Trajectories to Guide 'Moving Targets' in the Management of River Futures, River Res. Applic., 32, 823-835, doi:10.1002/rra.2930, 2016.

Bronstert, A., Bárdossy, A., Bismuth, C., Buiteveld, H., Disse, M., Engel, H., Fritsch, U., Hundecha, Y., Lammersen, R., Niehoff, D., and Ritter, N.: Multi-scale modelling of land-use change and river training effects on floods in the Rhine basin, River Res. Applic., 23, 1102-1125, doi:10.1002/rra.1036, 2007. 
Brunner, M. I., Seibert, J., and Favre, A.-C.: Representative sets of design hydrographs for ungauged catchments: A regional approach using probabilistic region memberships, Advances in Water Resources, 112, 235-244, doi:10.1016/j.advwatres.2017.12.018, 2018.

Burby, R. J. and French, S. P.: Coping With Floods: The Land Use Management Paradox, Journal of the American Planning Association, 47, 289-300, doi:10.1080/01944368108976511, 2007.

Cammerer, H. and Thieken, A. H.: Historical development and future outlook of the flood damage potential of residential areas in the Alpine Lech Valley (Austria) between 1971 and 2030, Reg Environ Change, 13, 999-1012, doi:10.1007/s10113-013-0407-9, 2013

Cammerer, H., Thieken, A. H., and Verburg, P. H.: Spatio-temporal dynamics in the flood exposure due to land use changes in the Alpine Lech Valley in Tyrol (Austria), Nat Hazards, 68, 1243-1270, doi:10.1007/s11069-012-0280-8, 2013.

Carisi, F., Domeneghetti, A., Gaeta, M. G., and Castellarin, A.: Is anthropogenic land subsidence a possible driver of riverine flood-hazard dynamics?: A case study in Ravenna, Italy, Hydrological Sciences Journal, 6, 1-16, doi:10.1080/02626667.2017.1390315, 2017.

Church, M. and Ferguson, R. I.: Morphodynamics: Rivers beyond steady state, Water Resour. Res., n/a, doi:10.1002/2014WR016862, 2015.

Corenblit, D., Davies, N. S., Steiger, J., Gibling, M. R., and Bornette, G.: Considering river structure and stability in the light of evolution: feedbacks between riparian vegetation and hydrogeomorphology, Earth Surface Processes and Landforms, n/a, doi:10.1002/esp.3643, 2014.

Coulthard, T. J. and Van De Wiel, Marco J.: Quantifying fluvial non linearity and finding self organized criticality?: Insights from simulations of river basin evolution, Geomorphology, 91, 216-235, doi:10.1016/j.geomorph.2007.04.011, 2007.

Croke, J., Denham, R., Thompson, C., and Grove, J.: Evidence of Self-Organized Criticality in riverbank mass failures: a matter of perspective?, Earth Surface Processes and Landforms, 40, 953-964, doi:10.1002/esp.3688, 2015.

Dessai, S. and Hulme, M.: Does climate adaptation policy need probabilities?, Climate Policy, 4, 107-128, doi:10.1080/14693062.2004.9685515, 2004.

Devkota, R. P. and Bhattarai, U.: Assessment of climate change impact on floods from a techno-social perspective, J. Flood Risk Manage, n/a-n/a, doi:10.1111/jfr3.12192, 2015. 
Di Baldassarre, G., Castellarin, A., and BRATH, A.: Analysis of the effects of levee heightening on flood propagation: example of the River Po, Italy, Hydrological Sciences Journal, 54, 1007-1017, doi:10.1623/hysj.54.6.1007, 2009.

Di Baldassarre, G., Kooy, M., Kemerink, J. S., and Brandimarte, L.: Towards understanding the dynamic behaviour of floodplains as human-water systems, Hydrol. Earth Syst. Sci., 17, 3235-3244, doi:10.5194/hess-17-3235-2013, 2013a.

Di Baldassarre, G., Viglione, A., Carr, G., Kuil, L., Salinas, J. L., and Blöschl, G.: Socio-hydrology: conceptualising human-flood interactions, Hydrol. Earth Syst. Sci., 17, 3295-3303, doi:10.5194/hess-173295-2013, 2013b.

590 Di Baldassarre, G., Viglione, A., Carr, G., Kuil, L., Yan, K., Brandimarte, L., and Blöschl, G.: DebatesPerspectives on socio-hydrology: Capturing feedbacks between physical and social processes, Water Resour. Res., 51, 4770-4781, doi:10.1002/2014WR016416, 2015.

Dixon, S. J., Sear, D. A., Odoni, N. A., Sykes, T., and Lane, S. N.: The effects of river restoration on catchment scale flood risk and flood hydrology, Earth Surf. Process. Landforms, 41, 997-1008, doi:10.1002/esp.3919, 2016.

Drost, U. and Ell, M.: Das neue Wasserrecht: Ein Lehrbuch für Ausbildung und Praxis in Bayern, 2., vollständig überarbeitete Auflage, Boorberg, Stuttgart, München, Hannover, Berlin, Weimar, Dresden, 323 Seiten, 2016.

Dutta, D., Herath, S., and Musiake, K.: A mathematical model for flood loss estimation, Journal of Hydrology, 277, 24-49, doi:10.1016/S0022-1694(03)00084-2, 2003.

Elmer, F., Hoymann, J., Düthmann, D., Vorogushyn, S., and Kreibich, H.: Drivers of flood risk change in residential areas, Nat. Hazards Earth Syst. Sci., 12, 1641-1657, doi:10.5194/nhess-12-1641-2012, 2012.

Ernst, J., Dewals, B. J., Detrembleur, S., Archambeau, P., Erpicum, S., and Pirotton, M.: Micro-scale flood risk analysis based on detailed 2D hydraulic modelling and high resolution geographic data, Nat Hazards, 55, 181-209, doi:10.1007/s11069-010-9520-y, 2010.

Figueiredo, R., Schröter, K., Weiss-Motz, A., Martina, M. L. V., and Kreibich, H.: Improving accuracy and quantifying uncertainty in flood loss estimations through the use of multi-model ensembles, Nat. Hazards Earth Syst. Sci. Discuss., 1-34, doi:10.5194/nhess-2017-349, 2017.

Finsler, H. C.: Das Amt Fraubrunnen um 1820-1830, Blätter 3, 6 und 9., Landschaftswandel und wirtschaftliche Umstrukturierung seit dem frühen 19. Jahrhundert., Fraubrunnen, 1978. 
Früh-Müller, A., Wegmann, M., and Koellner, T.: Flood exposure and settlement expansion since pre-industrial times in 1850 until 2011 in north Bavaria, Germany, Reg Environ Change, 15, 183-193, doi:10.1007/s10113-014-0633-9, 2015.

Fuchs, S., Keiler, M., Sokratov, S., and Shnyparkov, A.: Spatiotemporal dynamics: the need for an innovative approach in mountain hazard risk management, Nat Hazards, 68, 1217-1241, doi:10.1007/s11069-0120508-7, 2013.

Fuchs, S., Keiler, M., and Zischg, A.: A spatiotemporal multi-hazard exposure assessment based on property data, Nat. Hazards Earth Syst. Sci., 15, 2127-2142, doi:10.5194/nhess-15-2127-2015, 2015.

Fuchs, S., Keiler, M., Zischg, A., and Bründl, M.: The long-term development of avalanche risk in settlements considering the temporal variability of damage potential, Nat. Hazards Earth Syst. Sci., 5, 893-901, doi:10.5194/nhess-5-893-2005, 2005.

Fuchs, S., Röthlisberger, V., Thaler, T., Zischg, A., and Keiler, M.: Natural Hazard Management from a Coevolutionary Perspective: Exposure and Policy Response in the European Alps, Annals of the American Association of Geographers, 1-11, doi:10.1080/24694452.2016.1235494, 2016.

Gober, P. and Wheater, H. S.: Debates-Perspectives on socio-hydrology: Modeling flood risk as a public policy problem, Water Resour. Res., 51, 4782-4788, doi:10.1002/2015WR016945, 2015.

Gobiet, A., Kotlarski, S., Beniston, M., Heinrich, G., Rajczak, J., and Stoffel, M.: 21st century climate change in the European Alps-A review, Science of The Total Environment, 493, 1138-1151, doi:10.1016/j.scitotenv.2013.07.050, 2014.

Goldschmied, H.: Emmekorrektion 1. Sektion Kantonsgrenze Bern/Solothurn bis Grenze Burgdorf. Situationsplan km. 0-14. Massstab 1:5000. Aus: StAB BB 06.7.371, KantonBern, 1913.

Gregory, K. J.: The human role in changing river channels, 37th Binghamton Geomorphology SymposiumThe Human Role in Changing Fluvial Systems, 79, 172-191, doi:10.1016/j.geomorph.2006.06.018, 2006.

Guan, M., Carrivick, J. L., Wright, N. G., Sleigh, P. A., and Staines, K. E.H.: Quantifying the combined effects of multiple extreme floods on river channel geometry and on flood hazards, Journal of Hydrology, 538, 256-268, doi:10.1016/j.jhydrol.2016.04.004, 2016.

Hall, J., Arheimer, B., Borga, M., Brázdil, R., Claps, P., Kiss, A., Kjeldsen, T. R., Kriaučiūnienè, J., Kundzewicz, Z. W., Lang, M., Llasat, M. C., Macdonald, N., McIntyre, N., Mediero, L., Merz, B., Merz, R., Molnar, P., Montanari, A., Neuhold, C., Parajka, J., Perdigão, R. A. P., Plavcová, L., Rogger, M., 
changes in Europe: A state-of-the-art assessment, Hydrol. Earth Syst. Sci., 18, 2735-2772, doi:10.5194/hess-18-2735-2014, 2014.

Herget, J., Dikau, R., Gregory, K. J., and Vandenberghe, J.: The fluvial system — Research perspectives of its past and present dynamics and controls, Geomorphology, 92, 101-105, doi:10.1016/j.geomorph.2006.07.034, 2007.

Himmelsbach, I., Glaser, R., Schoenbein, J., Riemann, D., and Martin, B.: Flood risk along the upper Rhine since AD 1480, Hydrol. Earth Syst. Sci. Discuss., 12, 177-211, doi:10.5194/hessd-12-177-2015, 2015.

Hirabayashi, Y., Mahendran, R., Koirala, S., Konoshima, L., Yamazaki, D., Watanabe, S., Kim, H., and Kanae, S.: Global flood risk under climate change, Nature Climate change, 3, 816-821, doi:10.1038/nclimate1911, 2013.

Hollis, G. E.: The effect of urbanization on floods of different recurrence interval, Water Resour. Res., 11, 431435, doi:10.1029/WR011i003p00431, 1975.

Hooke, J. M.: Human impacts on fluvial systems in the Mediterranean region, 37th Binghamton Geomorphology SymposiumThe Human Role in Changing Fluvial Systems, 79, 311-335, doi:10.1016/j.geomorph.2006.06.036, 2006.

Hufschmidt, G., Crozier, M., and Glade, T.: Evolution of natural risk: Research framework and perspectives, Nat. Hazards Earth Syst. Sci., 5, 375-387, doi:10.5194/nhess-5-375-2005, 2005.

Hundecha, Y. and Merz, B.: Exploring the relationship between changes in climate and floods using a modelbased analysis, Water Resour. Res., 48, 3331, doi:10.1029/2011WR010527, 2012.

660 Hydrotec: Hochwasser-Aktionsplan Angerbach. Teil I: Berichte und Anlagen. Studie im Auftrag des Stua Dusseldorf, Aachen, Germany., 2001.

Jongman, B., Ward, P. J., and Aerts, J. C.J.H.: Global exposure to river and coastal flooding: Long term trends and changes, Global Environmental Change, 22, 823-835, doi:10.1016/j.gloenvcha.2012.07.004, 2012.

Jonkman, S. N., Bočkarjova, M., Kok, M., and Bernardini, P.: Integrated hydrodynamic and economic modelling of flood damage in the Netherlands, Special Section: Integrated Hydro-Economic Modelling for Effective and Sustainable Water Management, 66, 77-90, doi:10.1016/j.ecolecon.2007.12.022, 2008.

KAWA Amt für Wald des Kantons Bern: LiDAR Bern - Airborne Laserscanning. Gesamtbericht Befliegung Befliegung Kanton Bern 2011 - 2014., 2015. 
Keiler, M., Knight, J., and Harrison, S.: Climate change and geomorphological hazards in the eastern European Alps, Philosophical transactions. Series A, Mathematical, physical, and engineering sciences, 368, 24612479, doi:10.1098/rsta.2010.0047, 2010.

Keiler, M., Sailer, R., Jörg, P., Weber, C., Fuchs, S., Zischg, A., and Sauermoser, S.: Avalanche risk assessment; a multi-temporal approach, results from Galtür, Austria, Nat. Hazards Earth Syst. Sci., 6, 637651, doi:10.5194/nhess-6-637-2006, 2006.

Keiler, M., Zischg, A., Fuchs, S., Hama, M., and Stötter, J.: Avalanche related damage potential - changes of persons and mobile values since the mid-twentieth century, case study Galtür, Nat. Hazards Earth Syst. Sci., 5, 49-58, doi:10.5194/nhess-5-49-2005, 2005.

Kiss, T., Fiala, K., and Sipos, G.: Alterations of channel parameters in response to river regulation works since 1840 on the Lower Tisza River (Hungary), Geomorphology, 98, 96-110, doi:10.1016/j.geomorph.2007.02.027, 2008.

Kundzewicz, Z. W., Kanae, S., Seneviratne, S. I., Handmer, J., Nicholls, N., Peduzzi, P., Mechler, R., Bouwer, L. M., Arnell, N., Mach, K., Muir-Wood, R., Brakenridge, G. R., Kron, W., Benito, G., Honda, Y., Takahashi, K., and Sherstyukov, B.: Flood risk and climate change: global and regional perspectives, Hydrological Sciences Journal, 59, 1-28, doi:10.1080/02626667.2013.857411, 2014.

Lane, S. N.: Natural flood management, WIREs Water, 4, e1211, doi:10.1002/wat2.1211, 2017.

Liu, J., Hertel, T. W., Diffenbaugh, N. S., Delgado, M. S., and Ashfaq, M.: Future property damage from flooding: Sensitivities to economy and climate change, Climatic Change, 132, 741-749, doi:10.1007/s10584-015-1478-z, 2015.

Löschner, L., Herrnegger, M., Apperl, B., Senoner, T., Seher, W., and Nachtnebel, H. P.: Flood risk, climate change and settlement development: A micro-scale assessment of Austrian municipalities, Reg Environ Change, 42, 125, doi:10.1007/s10113-016-1009-0, 2016.

Luder, F.: Situationsplan von Burgdorf, erstellt nach dem Kataster (Druck). Massstab: 1:2000. Aus: BAB PP 315., 1928.

Marani, M. and Rigon, R.: Self-Organized River Basin Landscapes - Fractal and Multifractal Characteristics, doi:10.1029/94WR01493, 1994.

Marchese, E., Scorpio, V., Fuller, I., McColl, S., and Comiti, F.: Morphological changes in alpine rivers following the end of the Little Ice Age, Geomorphology, doi:10.1016/j.geomorph.2017.07.018, 2017. 
Mazzorana, B., Levaggi, L., Keiler, M., and Fuchs, S.: Towards dynamics in flood risk assessment, Nat.

Hazards Earth Syst. Sci., 12, 3571-3587, doi:10.5194/nhess-12-3571-2012, 2012.

Merz, B., Aerts, J., Arnbjerg-Nielsen, K., Baldi, M., Becker, A., Bichet, A., Blöschl, G., Bouwer, L. M., Brauer, A., Cioffi, F., Delgado, J. M., Gocht, M., Guzzetti, F., Harrigan, S., Hirschboeck, K., Kilsby, C., Kron, W., Kwon, H.-H., Lall, U., Merz, R., Nissen, K., Salvatti, P., Swierczynski, T., Ulbrich, U., Viglione, A., Ward, P. J., Weiler, M., Wilhelm, B., and Nied, M.: Floods and climate: Emerging perspectives for flood risk assessment and management, Nat. Hazards Earth Syst. Sci., 14, 1921-1942, doi:10.5194/nhess-14-1921$2014,2014$.

Merz, B., Hall, J., Disse, M., and Schumann, A.: Fluvial flood risk management in a changing world, Nat. Hazards Earth Syst. Sci., 10, 509-527, doi:10.5194/nhess-10-509-2010, 2010.

Muñoz, L. A., Olivera, F., Giglio, M., and Berke, P.: The impact of urbanization on the streamflows and the 100-year floodplain extent of the Sims Bayou in Houston, Texas, International Journal of River Basin Management, 7, 1-9, doi:10.1080/15715124.2017.1372447, 2017.

Nadarajah, S.: Probability models for unit hydrograph derivation, Journal of Hydrology, 344, 185-189, doi:10.1016/j.jhydrol.2007.07.004, 2007.

Nicholls, S. and Crompton, J. L.: The effect of rivers, streams, and canals on property values, River Res. Applic., 36, 773, doi:10.1002/rra.3197, 2017.

715 Noël, P. H. and Cai, X.: On the role of individuals in models of coupled human and natural systems: Lessons from a case study in the Republican River Basin, Environmental Modelling \& Software, 92, 1-16, doi:10.1016/j.envsoft.2017.02.010, 2017.

O’Connell, P. E., Ewen, J., O’Donnell, G., and Quinn, P.: Is there a link between agricultural land-use management and flooding?, Hydrol. Earth Syst. Sci., 11, 96-107, doi:10.5194/hess-11-96-2007, 2007.

Papathoma-Köhle, M., Zischg, A., Fuchs, S., Glade, T., and Keiler, M.: Loss estimation for landslides in mountain areas - An integrated toolbox for vulnerability assessment and damage documentation, Environmental Modelling \& Software, 63, 156-169, doi:10.1016/j.envsoft.2014.10.003, 2015.

Pinter, N., Thomas, R., and Wlosinski, J. H.: Regional Impacts of Levee Construction and Channelization, Middle Mississippi River, USA, in: Flood Issues in Contemporary Water Management, Marsalek, J., Watt, W. E., Zeman, E., and Sieker, F. (Eds.), NATO Science Series, Series 2. Environment Security, 71, Springer Netherlands, Dordrecht, 351-361, 2000. 
Pinter, N., Thomas, R., and Wlosinski, J. H.: Assessing flood hazard on dynamic rivers, Eos Trans. AGU, 82, 333, doi:10.1029/01EO00199, 2001.

Pinter, N., van der Ploeg, Rienk R., Schweigert, P., and Hoefer, G.: Flood magnification on the River Rhine, Hydrol. Process., 20, 147-164, doi:10.1002/hyp.5908, 2006.

Posey, J.: The determinants of vulnerability and adaptive capacity at the municipal level: Evidence from floodplain management programs in the United States, Global Environmental Change, 19, 482-493, doi:10.1016/j.gloenvcha.2009.06.003, 2009.

Rai, R. K., Sarkar, S., and Singh, V. P.: Evaluation of the Adequacy of Statistical Distribution Functions for Deriving Unit Hydrograph, Water Resour Manage, 23, 899-929, doi:10.1007/s11269-008-9306-0, 2009.

Remo, J. W.F. and Pinter, N.: Retro-modeling the Middle Mississippi River, Journal of Hydrology, 337, 421435, doi:10.1016/j.jhydrol.2007.02.008, 2007.

Remo, J. W.F., Pinter, N., and Heine, R.: The use of retro- and scenario-modeling to assess effects of 100+ years river of engineering and land-cover change on Middle and Lower Mississippi River flood stages, Journal of Hydrology, 376, 403-416, doi:10.1016/j.jhydrol.2009.07.049, 2009.

Ritter, J.: Plan der Emmenkorrektion von Joseph Ritter: Abschnitt der Emme zwischen Ziegelbrücke und Eysteg (nach dem Emmenplan von J. A. Riediger). Massstab k.A. Aus: BAB PP 151, 1804.

Rogger, M., Agnoletti, M., Alaoui, A., Bathurst, J. C., Bodner, G., Borga, M., Chaplot, V., Gallart, F., Glatzel, G., Hall, J., Holden, J., Holko, L., Horn, R., Kiss, A., Kohnová, S., Leitinger, G., Lennartz, B., Parajka, J., Perdigão, R., Peth, S., Plavcová, L., Quinton, J. N., Robinson, M., Salinas, J. L., Santoro, A., Szolgay, J., Tron, S., van den Akker, J.J.H., Viglione, A., and Blöschl, G.: Land-use change impacts on floods at the catchment scale - Challenges and opportunities for future research, Water Resour. Res., doi:10.1002/2017WR020723, 2017.

Röthlisberger, V., Zischg, A., and Keiler, M.: Spatiotemporal aspects of flood exposure in Switzerland, E3S Web Conf., 7, 8008, doi:10.1051/e3sconf/20160708008, 2016.

Röthlisberger, V., Zischg, A. P., and Keiler, M.: Identifying spatial clusters of flood exposure to support decision making in risk management, Science of The Total Environment, 598, 593-603, doi:10.1016/j.scitotenv.2017.03.216, 2017.

Ryffel, A. N., Rid, W., and Grêt-Regamey, A.: Land use trade-offs for flood protection: A choice experiment with visualizations, Ecosystem Services, 10, 111-123, doi:10.1016/j.ecoser.2014.09.008, 2014. 
Salzmann, N., Huggel, C., Nussbaumer, S. U., and Ziervogel, G.: Climate Change Adaptation Strategies - An Upstream-downstream Perspective, Springer International Publishing; Imprint; Springer, Cham, 1 online resource (x, 292, 2016.

Sear, D. A. and Newson, M. D.: Environmental change in river channels: a neglected element. Towards geomorphological typologies, standards and monitoring, Detecting Environmental Change: Science and Society, 310, 17-23, doi:10.1016/S0048-9697(02)00619-8, 2003.

Serinaldi, F. and Grimaldi, S.: Synthetic Design Hydrographs Based on Distribution Functions with Finite Support, J. Hydrol. Eng., 16, 434-446, doi:10.1061/(ASCE)HE.1943-5584.0000339, 2011.

Slater, L. J., Singer, M. B., and Kirchner, J. W.: Hydrologic versus geomorphic drivers of trends in flood hazard, Geophys. Res. Lett., 42, 370-376, doi:10.1002/2014GL062482, 2015.

Staffler, H., Pollinger, R., Zischg, A., and Mani, P.: Spatial variability and potential impacts of climate change on flood and debris flow hazard zone mapping and implications for risk management, Nat. Hazards Earth Syst. Sci., 8, 539-558, doi:10.5194/nhess-8-539-2008, 2008.

Surian, N. and Rinaldi, M.: Morphological response to river engineering and management in alluvial channels in Italy, Geomorphology, 50, 307-326, doi:10.1016/S0169-555X(02)00219-2, 2003.

Thaler, T., Zischg, A., Keiler, M., and Fuchs, S.: Allocation of risk and benefits-distributional justices in mountain hazard management, Reg Environ Change, doi:10.1007/s10113-017-1274-6, 2018.

Thieken, A. H., Cammerer, H., Dobler, C., Lammel, J., and Schöberl, F.: Estimating changes in flood risks and benefits of non-structural adaptation strategies - a case study from Tyrol, Austria, Mitig Adapt Strateg Glob Change, 21, 343-376, doi:10.1007/s11027-014-9602-3, 2016.

Tobin, G. A.: THE LEVEE LOVE AFFAIR: A STORMY RELATIONSHIP?, J Am Water Resources Assoc, 31, 359-367, doi:10.1111/j.1752-1688.1995.tb04025.x, 1995.

Totschnig, R., Sedlacek, W., and Fuchs, S.: A quantitative vulnerability function for fluvial sediment transport, Nat Hazards, 58, 681-703, doi:10.1007/s11069-010-9623-5, 2011.

UNISDR: Making development sustainable: The future of disaster risk management, Global assessment report on disaster risk reduction, 4.2015, United Nations, Geneva, 311 pp., 2015.

van Triet, N. K., Dung, N. V., Fujii, H., Kummu, M., Merz, B., and Apel, H.: Has dyke development in the Vietnamese Mekong Delta shifted flood hazard downstream?, Hydrol. Earth Syst. Sci., 21, 3991-4010, doi:10.5194/hess-21-3991-2017, 2017. 
Farshi, D., Mueller, R., Rousselot, P., Veprek, R., and Faeh, R.: BASEMENT - Basic Simulation

Environment for Computation of Environmental Flow and Natural Hazard Simulation., Zurich, 2017.

Vischer, D.: Die Geschichte des Hochwasserschutzes in der Schweiz, Berichte des BWG, Serie Wasser, 5, Bern, 209 pp., 2003.

Vorogushyn, S. and Merz, B.: Flood trends along the Rhine: The role of river training, Hydrol. Earth Syst. Sci., 17, 3871-3884, doi:10.5194/hess-17-3871-2013, 2013.

White, G.: Human adjustment to floods, Department of Geography, University of Chicago, USA, 1945.

Wiering, M., Liefferink, D., and Crabbé, A.: Stability and change in flood risk governance: On path dependencies and change agents, J Flood Risk Management, doi:10.1111/jfr3.12295, 2017.

Winsemius, H. C., Aerts, Jeroen C. J. H., van Beek, Ludovicus P. H., Bierkens, Marc F. P., Bouwman, A., Jongman, B., Kwadijk, J. C. J., Ligtvoet, W., Lucas, P. L., van Vuuren, D. P., and Ward, P. J.: Global drivers of future river flood risk, Nature Climate change, doi:10.1038/nclimate2893, 2015.

Wirth, S. B., Girardclos, S., Rellstab, C., and Anselmetti, F. S.: The sedimentary response to a pioneer geoengineering project: Tracking the Kander River deviation in the sediments of Lake Thun (Switzerland), Sedimentology, 58, 1737-1761, doi:10.1111/j.1365-3091.2011.01237.x, 2011.

Wise, R. M., Fazey, I., Stafford Smith, M., Park, S. E., Eakin, H. C., van Archer Garderen, E.R.M., and Campbell, B.: Reconceptualising adaptation to climate change as part of pathways of change and response, Global Environmental Change, 28, 325-336, doi:10.1016/j.gloenvcha.2013.12.002, 2014.

Zhao, T. and Shao, Q.: Detecting floodplain inundation based on the upstream-downstream relationship, Journal of Hydrology, 530, 195-205, doi:10.1016/j.jhydrol.2015.09.056, 2015.

Zischg, A.: River corrections and long-term changes in flood risk in the Aare valley, Switzerland, E3S Web Conf., 7, 11010, doi:10.1051/e3sconf/20160711010, 2016.

Zischg, A., Schober, S., Sereinig, N., Rauter, M., Seymann, C., Goldschmidt, F., Bäk, R., and Schleicher, E.: Monitoring the temporal development of natural hazard risks as a basis indicator for climate change adaptation, Nat Hazards, 67, 1045-1058, doi:10.1007/s11069-011-9927-0, 2013.

Zischg, A. P., Felder, G., Weingartner, R., Quinn, N., Coxon, G., Neal, J., Freer, J., and Bates, P.: Effects of variability in probable maximum precipitation patterns on flood losses, Hydrol. Earth Syst. Sci. Discuss., 124, doi:10.5194/hess-2017-758, 2018 a. 
Zischg, A. P., Mosimann, M., Bernet, D. B., and Röthlisberger, V.: Validation of 2D flood models with insurance claims, Journal of Hydrology, 557, 350-361, doi:10.1016/j.jhydrol.2017.12.042, 2018b. 
Hazard mapping and land use planning in Switzerland

In Switzerland, all municipalities are obliged to elaborate a hazard map. This hazard map classifies an examined area into five categories with respect to the magnitude and frequency of potential flood events (Fuchs et al. 2017).

Red zones (high hazard) indicate areas where residents are at risk both inside and outside of buildings and sudden destruction of a building is possible upon impact with process-related forces. Blue zones (moderate hazard) indicate those areas where people are at risk outside of buildings and moderate destruction of buildings may be possible. Yellow zones (low hazard) delimit areas where flood hazard may lead to considerable monetary loss at buildings, but people are rarely at risk. The main criteria for classification of the hazard is the flood intensity with thresholds at $0.5 \mathrm{~m}$ or $0.5 \mathrm{~m}^{2} / \mathrm{s}$ (yellow and blue), between $0.5 \mathrm{~m}$ and $2.0 \mathrm{~m}$ or $0.5 \mathrm{~m}^{2} / \mathrm{s}$ and $2.0 \mathrm{~m}^{2} / \mathrm{s}$ (yellow and blue), or exceeding $2.0 \mathrm{~m}$ or $2.0 \mathrm{~m}^{2} / \mathrm{s}$ (red). The probability of occurrence of the underlying flood hazard is used to further distinguish the hazard zones for up to 30 year (blue and red), 30-100 year (yellow, blue and red) and 100 to 300 year (yellow and red) return periods. Areas within the investigation focus but without a potential hazard are coloured as white. Areas susceptible to a residual risk are coloured in yellow-white striped, i.e. areas in which the probability of occurrence of a flood event is less than one in 300 years. The hazard maps were elaborated in a target scale of 1:2’000 to $1: 10^{\prime} 000$.

When implemented into the legally binding land use regulation plan of the municipality, the hazard map becomes relevant for houseowners and landowners. The Guidelines for the Consideration of the Hydrological Hazards in Land-Use Planning Activities were approved in 1997 (BWW, BRP, and BUWAL 1997). In red zones, the

840 authorities are obliged to restrict any construction of new houses. Thus, land parcels within red zones cannot be sold with a value of land suitable for construction. Houses that are located in red zones before the implementation of the hazard map are not allowed to be extended, nor their type of use could be modified. In blue zones, new houses are only permitted to be constructed if their constructor guarantees to implement protection measures that prevent losses from flooding. Existing houses have to be adapted in case of a planned modification or extension. In yellow zones, the construction of critical buildings, e.g. schools and public buildings, is allowed only after a specific sensitivity analysis of the planned project (Kanton Zürich 2014).

\section{References}


BWW, BRP, and BUWAL. 1997. Berücksichtigung der Hochwassergefahren bei raumwirksamen Tätigkeiten.

850 Biel und Bern: Bundesamt für Wasserwirtschaft, Bundesamt für Raumplanung, Bundesamt für Umwelt, Wald und Landschaft.

Fuchs, S., Röthlisberger, V., Thaler, T., Zischg, A., and Keiler, M.: Natural Hazard Management from a Coevolutionary Perspective: Exposure and Policy Response in the European Alps, Annals of the American Association of Geographers, 1-11, doi:10.1080/24694452.2016.1235494, 2017.

855 Kanton Zürich. 2014. Gefahrenkarte Kanton Zürich - Lesehilfe. Zürich 